\title{
Transdisciplinary relationship between mathematics and accounting
}

Author:
Msizi V. Mkhize ${ }^{1}$
Affiliation:
'School of Accounting,
Economics and Finance,
University of KwaZulu-Natal,
South Africa
Corresponding author:
Msizi Mkhize,
mkhizem4@ukzn.ac.za
Dates:
Received: 14 June 2017
Accepted: 18 Apr. 2018
Published: 28 Feb. 2019
mobile phone or
to read online.
Mkhize, M.V., 2019,
'Transdisciplinary relationship
between mathematics and
accounting', The Journal for
Transdisciplinary Research in
Southern Africa 15(1), a451.
https://doi.org/10.4102/
td.v15i1.451
Copyright:
Q
Q 2019. The Authors.
Licensee: AOSIS. This work
is licensed under the
Creative Commons
Attribution License.

Author:

Affiliation:

${ }^{1}$ School of Accounting,

South Africa

Corresponding author:

Msizi Mkhize,

Dates:

How to cite this article:

Mkhize, M.V., 2019,

between mathematics and

accounting', The Journal for

Transdisciplinary Research in

https://doi.org/10.4102/

td.v15i1.45

Copyright:

Licensee: AOSIS. This work

is licensed under the

Creative Commons

Attribution License.
Accounting and mathematics are closely related. There is little mathematics content that a profound relationship exists between mathematics and accounting. There is, however, a limited understanding of the nature of this relationship and the extent to which mathematics influences the teaching and learning of accounting. Accounting scholars perform a variety of calculations in accounting courses, making mathematics integral to the successful study of accounting. This investigative study is hinged on transdisciplinary relationship between mathematics and accounting in an undergraduate teacher education degree. The purpose of this article was to identify the mathematics topics required for the study of accounting in a Bachelor of Education (BEd) degree curriculum. A detailed analysis of the BEd Accounting course content for Accounting I, II and III regarding mathematical topics students encounter in their accounting modules was undertaken. A content analysis in the form documents was employed. Accounting course packs were analysed for mathematics required in a BEd curriculum. The analysis of accounting course packs revealed a range of mathematical content required for accounting. This finding confirmed the mathematical content needed for accounting, as identified under literature review. This article concludes with the implications for basic education, higher education, textbook writers, curriculum specialists and international policymakers.

\section{Introduction}

Mathematics is related to accounting but not as interlinked as people may believe or sometimes, that you should have a lot maths to take accounting (Babalola \& Abiola 2013). Accounting scholars perform a variety of calculations in accounting courses. This makes the understanding of mathematics integral to the successful study of accounting. There is a need for learning accounting from the perspective of mathematics (Warsono, Darmawan \& Ridha 2009). Accounting is defined as a 'process of collecting, measuring, analysing and communicating information to and decision making within the business and other organisations' (University of Glasgow 2014), whereas mathematics is defined as 'the science that studies and explains numbers quantities, measurements, and the relations between them' (Webster 2018). The majority of accounting definitions assert that accounting requires numerical and analytical skills which are also integral elements of mathematics (Shaftel \& Shaftel 2005). Academics around the world report, lack of adequate mathematical knowledge and computational skills of beginning students (Fedoryshyn et al. 2010; Heck \& Van Gastel 2006). The experiences of students at tertiary level, particularly during the first-year, are significantly informed by students' experiences at school level(Jacobs 2006). The dismal mathematical competence of South African high school learners is reflected in the World Economic Forum Global Competitiveness Report 2012/2013 that ranks South Africa last out of 148 countries in mathematics and science education (Schwab, Sala-i-Martin \& Brende 2013). In South Africa, mathematics is compulsory in General Education and Training (GET) - Grades R-9, but in Further Education and Training (FET) - Grades 10-12 learners enrol for mathematics or Mathematical Literacy. Either mathematics or Mathematical Literacy is an entry requirement for a Bachelor of Education (BEd) Accounting degree at the higher education institution (HEI) which is the setting for this study. The entry requirement into BEd Accounting degree in the School of Education at this HEI is Grade 12 mathematics or Mathematical Literacy and Grade 12 Accounting (HEI 2013). Chantyl Mulder, a senior executive of the South African Institute of Chartered Accountants (2010), emphasises that mathematics is the key to a prosperous and fulfilling future and that the South African economy is crying out for the skills, which require learners to study mathematics, not Mathematical Literacy.

\section{Purpose of the study}

The aim of this study was to investigate the transdisciplinary relationship between mathematics and accounting in a BEd curriculum at the HEI, with the aim of informing higher education pedagogy as it relates to teaching and learning in accounting. 


\section{Research question}

What mathematics topics are required for the study of accounting in a BEd degree?

\section{Literature review}

\section{The disciplines of Mathematics and Accounting}

The disciplines of Mathematics and Accounting are discussed under two sub-categories: philosophy and similarities and differences between the disciplines of Mathematics and Accounting.

\section{Philosophy}

The relationship between mathematics and accounting or bookkeeping is very old and the first published treatise on the double-entry principle appeared in 1494 in a book on mathematics by Luca Pacioli, entitled Summa de Arithmetica, Geometria, Proportioni et Proportionalita (Mattessich 2005; Warsono et al. 2009). Commenting on Pacioli's book, Ellerman (2009) states that:

The success in maintaining the two-sided accounting debits and credits, the double-entry principle, and the trial balance in both cases provide strong evidence that the formulation correctly captures the double-entry method in mathematical form. (p. 17)

In short, the double-entry principle means that the financial transaction contains two or more entries - flow of money from one account to one or more other accounts. For every debit (credit) entry there is a corresponding credit (debit) entry, and the value of debits must be equal to the value of credits. This ensures arithmetical accuracy of the recordings of financial transactions (Ellerman 2009; Haiden 2009; Myburgh, Fouche \& Cloete 2011; Warsono et al. 2009). For example, if the first account is credited (Cr) with an amount, then the second account must be debited (Dr) with the corresponding amount. If the first account is Dr with an amount, then the second account must be $\mathrm{Cr}$ with the corresponding amount.

\section{Similarities and differences between the disciplines of Mathematics and Accounting}

Accounting requires thinking that is careful and logical. From this logic, accounting has some similarity with mathematics and this probably why taking mathematics classes helps with accounting classes (Babalola \& Abiola 2013). In addition, Serai (2014) points out that mathematics and accounting both involve critical thinking, but are very different fields in different departments. At tertiary level, accounting degrees are found under the management or commerce discipline, while mathematics degrees are found under the science discipline. Another study by Tahir and AbuBakar (2007), exploring business students' beliefs in learning mathematics in a university mathematics class, show that learning mathematics by way of accounting, finance, management, marketing and business in general not only builds students' ability to think analytically but also develops skills of reasoning and problem-solving. Budnick (1993) points out, moreover, that the objective, in improving the level of quantitative sophistication possessed by business, accounting, economics and social sciences students, is not to make these students mathematicians, but to make them as comfortable as possible in an environment which used quantitative analysis.

\section{Mathematics required in learning accounting}

According to Thomason (2013) and Babalola and Abiola (2013), the advantage of a strong mathematical background is that it improves an accountant's cognitive ability. A variety of accounting activities require the employment of mathematics or mathematical principles.

Understanding what mathematics competences or skills are required can assist individuals in business processes in the following ways:

- Mathematical calculations: It is vital to have basic mathematics and algebra skills to complete accounting tasks or activities as they are full of basic and advanced calculations and report accurate financial information.

- Word problems: Word problems that arise in accounting usually relate to essential mathematical concepts. Therefore, reading skills are needed in addition to mathematical competence.

- Time value of money concepts: Problems occur in accounting in relationship to time value of money and require the use of various mathematical abilities.

- Other skills: There are other important skills that go beyond mathematics and accounting abilities, such as communication skills. Relatively little mathematics is required for studying accounting.

As listed by Mostyn (2008b), a chartered professional accountant, the mathematics knowledge essential for accounting includes topics such as place-value numerical system, arithmetic operations, decimals, percentages, positive and negative numbers, fractions, averages, the weighted average, linear equations and formulas. Walton (2009) lists the required mathematics topics for accounting as basic numeracy, ratio and proportions, percentages and averages, and formulas. In addition, Babalola and Abiola (2013) note that some schools or disciplines may require more advanced mathematics topics such as linear programming or calculus for accounting majors (see Table 1).

Discussions on previous studies on the importance of mathematics in accounting and on the issue of mathematics, Mathematical Literacy and quantitative methods as a prerequisite follow next. 
TABLE 1: Summary of mathematical content needed for accounting.

\begin{tabular}{lll}
\hline TABLE 1: Summary of mathem & Specific content & Description \\
\hline Number and operations & Place-value numerical system & Positioning numbers in a place-value numerical system. \\
& Basic arithmetic operations & The four basic operations,,$+- \times, \div$, BOMDAS or BODMAS rule. \\
& Rational numbers & Expressing amounts as fractions, decimals and percentages. Rounding off amounts with decimal amount. \\
& Integers & Adding, subtracting, multiplying and dividing numbers that are positive and negative. \\
& Ratio and proportions & Expressing numerical relationships as ratios, rates, proportions and averages. \\
& Exponents & Understanding calculations with exponents. \\
Patterns and algebra & Formulas & Substituting and changing the subject of the formula. \\
& Algebraic equations & Working with linear equations and exponential calculations. \\
& Mathematical modelling & Creating mathematical formula/equation from a real-life context or word problem. \\
& Financial mathematics & Performing time value of money calculations. \\
Data handling and Probability & Statistics & Creating tables and understanding calculations with forecasts or projections, knowing statistical issues (i.e. mean).
\end{tabular}

Please see the full reference list of the article, Mkhize, M.V., 2018, 'Transdisciplinary relationship between mathematics and accounting', The Journal for Transdisciplinary Research in Southern Africa 15(1), a451. https://doi.org/10.4102/td.v15i1.451, for more information.

BOMDAS, Brackets, of, multiplication, division, addition and subtraction; BODMAS, brackets, of, division, multiplication, addition and subtraction.

\section{Previous studies on the importance of mathematics in accounting}

\section{Some research}

In several studies, mathematics knowledge positively influenced students' achievement in accounting learning. Gist, Goedde and Ward (1996) and Pritchard, Potter and Saccucci (2004) examined the key factors that influence student choice of a business major and found that students who performed best in accounting had better calculation and algebra skills. Rossman (2006) warned that students who try to memorise shortcut methods to work through accounting problems without grasping the essential concepts are more likely to experience mathematical anxiety. Students may be able to perform a mathematical accounting problem in a contrived textbook context, but may have difficulty applying the knowledge in other accounting situations if essential mathematics principles involved are not mastered. Chinn (2008) and Naidoo (2012) reported that, in both mathematics and accounting, there is either a right or a wrong answer and that students are expected to work at a quick pace on exercises or assessments. Fedoryshyn et al. (2010), who examined whether a student's arithmetic reasoning ability had an effect on his or her performance in a first principles of an accounting course, found a high significant association between arithmetic reasoning skills and a student's final accounting average mark in the entry-level course. They further revealed that mathematical reasoning ability alone is not a major determinant of a student's final accounting course average mark.

Equally important, a study of 526 students in a 3-year accounting degree, by (Koh \& Koh 1999), showed that students' performance was positively related to academic aptitude, mathematics background and previous work experience. This study also found that male students outperformed female students and younger students outperformed mature-age entrants. Shi and Paucar-Caceres (2011) investigated the impacts of learning mathematics on studying accounting and finance courses at HEIs in Britain. In this investigation, lecturers reported that passion for learning mathematics on the part of accounting and finance students was gradually declining. Students' attitudes to learning mathematics suggested that they were unable to see the importance of learning mathematics for their courses and for their future professional life. The study also found that after they had succeeded on the first part of quantitative methods (mathematics) in finance in the first term, the students felt more confident at solving complex numerical computations and algorithm equations and plotting scatter graphs.

In contrast, Naser and Peel (1998) argued that mathematics grades, gender, age and school English, together with the type of school attended (private or public), did not impact significantly student performance in the principles of the accounting course. Instead, the university faculty originally attended was significantly associated with examination performance. Research by Barnes et al. (2009) on factors influencing success or failure in first-year accounting at a South African HEI (Central University of Technology) found that performance in Grade 12 mathematics was not significantly correlated with performance in first-year accounting ( $p=0.152>0.05)$. They also found no significant relationship between age and performance in first-year accounting $(p=0.240>0.05)$ and no significant difference was found between the performance of female students and male students $(p=0.69>0.05)$.

\section{Mathematics versus Mathematical Literacy: Quantitative methods as accounting prerequisites}

A study by Latief (2005) on throughput of University of Western Cape students who did at least one semester of third-year statistics suggested that in all quantitative subjects where mathematical calculations and abstract thinking are required, pure mathematics must be a prerequisite. Consistent with this study, Stainbank (2013), researching the impact of National Senior Certificate (NSC) mathematics on the performance of first-year commerce students, Bachelor of Commerce (BCom) Accounting or general BCom, found that performance in each university subject (ACC101, ECN101, ISTN101, MGNT101 and MAT134) was most strongly related with school mathematics performance. She concluded her study by suggesting that the entrance requirement should be raised to mathematics level 5 for all commerce students. If the mathematics remains at level 4 , then the university needs to provide academic support. She also noted that Mathematical Literacy was not accepted for BCom degrees. Walton (2009) stressed that if Mathematical Literacy is 
accepted, it will need support in some areas of mathematics, especially algebra. Correspondingly, a study by Stenberg, Varua and Yong (2010) on mathematics aptitude, attitude, secondary schools and student success in quantitative methods for a business subject in an Australian university found that commerce students, such as accounting and marketing students, require essential mathematical skills to successfully finish their degrees at a tertiary level. They suggested that student success in a core commerce subject is reliant on the student's mathematical aptitude, attitude and the type of secondary schooling (whether government or non-government). Tertiary institutions should recognise that high failure rates are because of inadequate mathematics exposure in secondary schooling, and corrective actions such as remedial lessons might not be sufficient. Specifying a minimum mathematics requirement for entry, or providing bridging programmes to ensure students have the essential basic mathematical skills, would increase student success in quantitative modules. In another study by Selesho (2000), investigating factors that influence the results of first-year accounting at Technikon Free State, respondents agreed that arithmetic or mathematics plays an important role in learning accounting and disclosed that even though mathematics was not a prerequisite for first-year accounting at the Technikon, one had to have an insight into arithmetic in order to face the challenges of the subject. A key point suggested

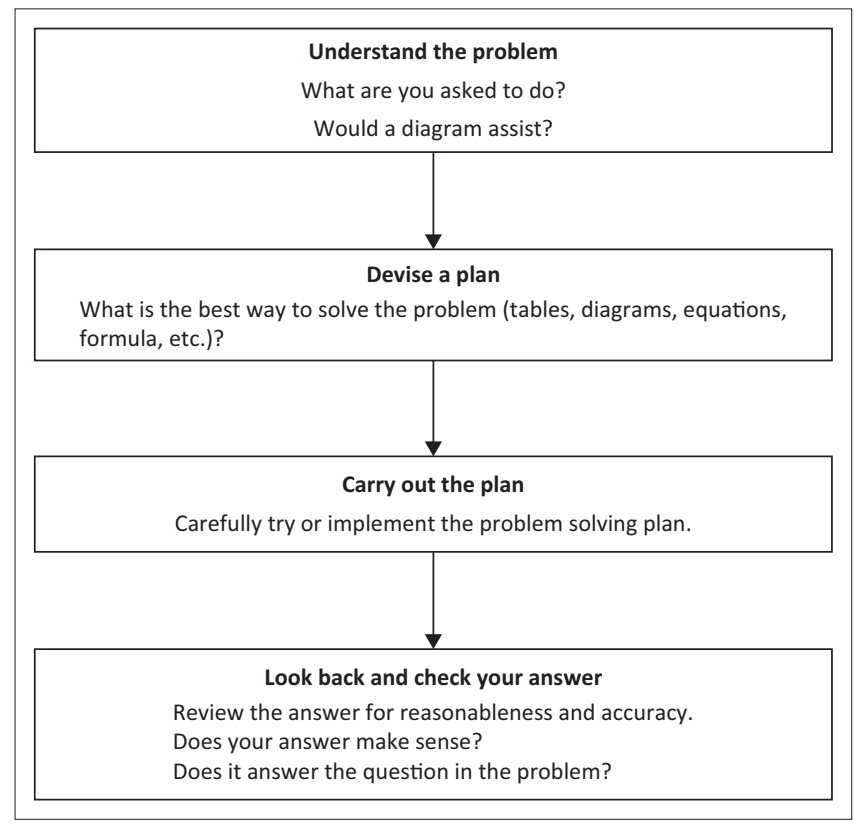

Source: Polya, G., 1957, How to solve it? A new aspect of mathematical method, Princeton University Press, Princeton

FIGURE 1: Polya's four steps for solving word problems. by Yunker, Yunker and Krull (2009) is that a mathematics pretest could be used to identify students at risk in principles of accounting courses, especially for those with measured low arithmetical, percentages and proportions skills.

In summary, studies recommend that mathematics should be a prerequisite for the study of accounting or a mathematics bridging programme. Discussion on the problem-solving skills in accounting is presented next.

\section{Problem-solving skills in accounting}

Accounting is a subject based on mathematical word problems (Babalola \& Abiola 2013; Thomason 2013). Polya (1957) suggested a set of practical rules for solving word problems so as to improve students' performance (see Figure 1). According to Costello and Darnley (2009:16), 'Polya recognised that mathematics teachers and students need interesting and generative problems, in order to keep the aspect of enquiry alive in the classroom'.

\section{Methodology}

A qualitative research design was adopted for this study in the form of content analysis using documents to examine the transdisciplinary relationship between mathematics and accounting.

A detailed analysis of the BEd Accounting course packs for first-, second- and third-year accounting (Table 2) was performed regarding mathematical topics that students encounter in their accounting modules. The main aim was to highlight specific aspects of mathematics required for the study of accounting in the BEd curriculum at the HEI. A method used by Walton (2009:55) to analyse the accounting textbooks and study guides for the mathematical requirements of BCom students at Nelson Mandela Metropolitan University was followed in this study. The list of topics identified was used as a basis for the analysis of the textbooks and study guides. Every time a mathematical calculation was observed, it was compared to the topics in the list to determine where it would fit in.

Accounting calculations are presented using the Department of Basic Education National Curriculum Statement mathematics topics: GET Phase mathematics - Grades R-9 and FET Phase mathematics - Grades 10-12. The main topics in the GET Phase mathematics Curriculum are as follows: number, operations

TABLE 2: Bachelor of Education Accounting curriculum at higher education institution.

\begin{tabular}{lll}
\hline Semester & Module year & Accounting topics \\
\hline $\begin{array}{l}\text { First } \\
\text { Second }\end{array}$ & First-year accounting & $\begin{array}{l}\text { Sole traders: accounting equation, subsidiary books and source documents, salaries and wages, final accounts and financial statements } \\
\text { Sole traders: bank reconciliation, periodic inventory system, disposal of assets and financial statements of a sole trader }\end{array}$ \\
First & $\begin{array}{l}\text { Partnership and companies: year-end adjustments, advanced financial statements, cash flow statements, and analysis and interpretation of } \\
\text { financial statements } \\
\text { Second }\end{array}$ & $\begin{array}{l}\text { Close corporations and cash budgets: advanced financial statements, analysis and interpretation of financial statements, cash budgets and } \\
\text { forecasted income statements }\end{array}$ \\
First & Third-year accounting & $\begin{array}{l}\text { Non-profit organisations, manufacturing and VAT accounting: advanced financial statements of NPO, manufacturing accounts and financial } \\
\text { statements of a manufacturing concern, VAT Accounting. } \\
\text { Retirement and liquidation of partnerships, branch accounting. }\end{array}$ \\
\hline Second & &
\end{tabular}

VAT, value-added tax. 
TABLE 3: Themes and sub-themes from content analysis of transdisciplinary relationship between mathematics and accounting.

\begin{tabular}{|c|c|c|}
\hline Theme (maths topics) 1 & General content focus & Sub-theme (sub-topics) \\
\hline 1. Number operations & $\begin{array}{l}\text { Development of the number sense that includes: } \\
\text { - the meaning of different kinds of numbers } \\
\text { relationship between different kinds of numbers } \\
\text { - representation of numbers in various ways } \\
\text { - the effect of operating with numbers } \\
\end{array}$ & $\begin{array}{l}\text { 1.1 Place-value numerical system } \\
\text { 1.2 Basic arithmetic operations and integers } \\
\text { 1.3 Rational numbers (percentages, fractions and decimals) } \\
\text { Ratios and proportions }\end{array}$ \\
\hline 2. Patterns and algebra & $\begin{array}{l}\text { A central part of this content area is for the learner to achieve efficient manipulative } \\
\text { skills in the use of algebra. It focuses on the: } \\
\text { - description of patterns and relationships through the use of symbolic expressions } \\
\text { and tables } \\
\text { - identification and analysis of regularities and change in patterns and relationships } \\
\text { that enable learners to make predictions and solve problems. }\end{array}$ & $\begin{array}{l}\text { 2.1 Formulas (substituting and hanging subject of formula) } \\
\text { 2.2 Algebraic equations (linear) } \\
\text { 2.3 Mathematical modelling } \\
\text { 2.4 Number operations } \\
\text { 2.5 Table method algebra } \\
\text { 2.6 Financial mathematics (formulas, substitutions, } \\
\text { logarithms and exponents) }\end{array}$ \\
\hline $\begin{array}{l}\text { 3. Data handling and } \\
\text { probability (statistics) }\end{array}$ & $\begin{array}{l}\text { Data handling involves asking questions and finding answers in order to describe events } \\
\text { and the social, technological and economic environment. Through the study of data } \\
\text { handling, the learner develops the skills to collect, organise, represent, analyse, interpret } \\
\text { and report data. } \\
\text { The study of probability enables the learner to develop skills and techniques for making } \\
\text { informed predictions, and describing randomness and uncertainty. }\end{array}$ & 3.1 Averages, weighted average and projections or forecasts \\
\hline
\end{tabular}

Source: Department of Basic Education, 2003, National Curriculum Statement Grades 10-12, pp. 10-11, Department of Basic Education, Pretoria

and relationships; patterns, functions and algebra; space, shape (geometry); measurement; and data handling. The main topics in the FET Phase mathematics Curriculum are as follows: functions; number patterns, sequences, series; finance, growth and decay; algebra; differential calculus; probability; Euclidean geometry and measurement; analytical geometry; trigonometry; and statistics (Table 3).

\section{Reliability, validity and trustworthiness}

A summary of the strategies and the criteria used to establish trustworthiness is as follows:

- Feedback received from the reviewers - member checks and peer confirmation of interpretations (trustworthiness).

- Confirmation of findings through triangulation: this provided evidence for validity.

- Reliability ensured through reference to the supervisors of my study and their positive feedback on the data interpretation.

\section{Ethical consideration}

Ethical clearance was obtained from the Human Research Ethics Committee of the higher education institution (reference number: HSS/0117/013D).

\section{Results}

The objective of this section is to highlight specific parts of mathematics topics required for the study of accounting in the BEd curriculum at the HEI research setting.

\section{Mathematics used in BEd Accounting: Examples of specific topics}

To illustrate the transdisciplinary relationship between Mathematics and Accounting, examples were selected from the first-, second- and third-year HEI BEd Accounting curriculum to identify specific topics in mathematics used in accounting. There was also an overlap in topics, but I have decided to present accounting calculations using the National Curriculum Statement mathematics topics (GET Phase and FET Phase mathematics), selected examples and explanations illustrated below.

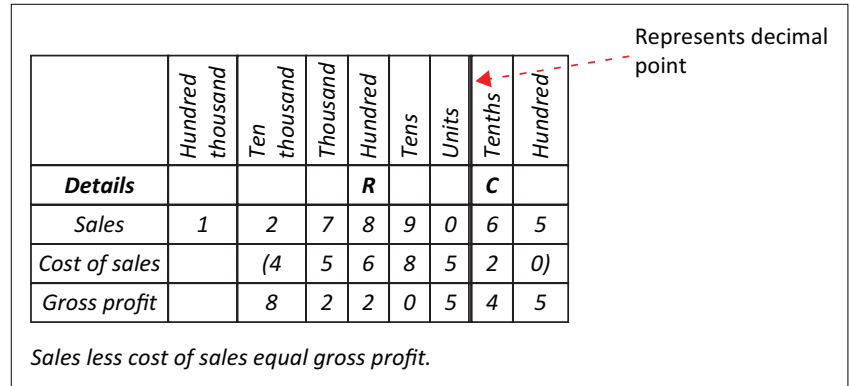

Source: From first-year BEd Accounting, 2015, Higher Education Institution, KwaZulu-Natal FIGURE 2: Positioning numbers in a place-value numerical system.

\section{Number and operations}

\section{Place-value numerical system}

In accounting, students need to be able to arrange amounts in the correct order. They need to know that a line between rands and cents represents a decimal point. Negative amounts are always reflected in brackets and positive amounts are reflected without brackets. Accounting also requires ability to work with big numbers.

Consider the following example: Extract from the statement of comprehensive income of Edgewood Traders for the year ended 31 December 2015, reflecting amounts in the placevalue system (Figure 2).

In analysing the accounting course packs, it became evident that BEd Accounting students need to be able to identify relevant amounts from a given information or write amounts in correct positions in a place-value numerical system. Inability to identify or write amounts could have a negative effect on students' performance.

\section{Basic arithmetic operations and integers}

Students need to have the knowledge of the four basic operations $(+-x \div$ ) because these operations are used in accounting. They need to read the question carefully and do as instructed. They need to know how to round off, because they may be required to round off to the nearest one decimal point, nearest two decimal points or nearest R1, R10 or R100, et cetera. Therefore, they need to know that amounts 
ending in 4 or less are rounded down (i.e. 1.233 becomes 1.24) and amounts ending in five or more are rounded up (i.e. 1.235 becomes 1.24). They also need to know about addition and subtraction and zero and be able to add, subtract, multiply and divide integers. They need to understand the logic of calculations when preparing source documents as these require knowledge of basic mathematical operations, integers and percentages, and they need to be able to use a calculator.

Consider the following example from first-year accounting: On 01 February 2015, Edgewood Traders sold goods to S. Khumalo on credit. Issue invoice No X02 address 12, Durban North Road, five trays @ R25.99 and 10 sets cutlery @ R45.99 (Figure 3).

\section{Rational numbers (fractions, percentages and decimals)}

Students need to understand percentages, fractions, and decimals to solve real-life accounting problems. They need to be able to convert or express percentage as a decimal (e.g. $90 \%=0.90$ ) by just moving the decimal point by two places to the left of the given number. They also need to be able to convert or express a percentage as a fraction by just dividing by 100 (e.g. $90 \%=\frac{90}{100}=0.90$, and 0.10 could be expressed as $\left.\frac{10}{100}\right)$. Students also need to be able to convert a mixed fraction $\left(33 \frac{1}{3}\right)$ into an improper fraction $\left(\frac{100}{3}\right)$. In many accounting tasks or activities, students will be required to perform percentage calculations.

Consider the following example (second-year accounting): Equipment bought on account from Jeena Wholesalers for R15000 less 10\% trade discount (see Figure 4).

Students must understand percentages and basic operations when performing calculations involving a trade discount. In order to record the correct amount in the creditors journal, students need to calculate the correct amount of this equipment. They are encouraged to master table

\begin{tabular}{|l|l|l|l|}
\hline \multicolumn{2}{|l|}{ CREDIT INVOICE } & \multicolumn{2}{l|}{ G01 } \\
\hline \multicolumn{2}{|l|}{$\begin{array}{l}\text { S. Khumalo } \\
\text { Durban North }\end{array} 000$} & \multicolumn{1}{l|}{$\begin{array}{l}\text { Edgewood Traders } \\
\text { Private Bag X1964 } \\
\text { Pinetown } 3610 \\
1 \text { February 2015 }\end{array}$} \\
\hline \multirow{2}{*}{ Quantity } & Description & Unit price & Amount \\
\hline 5 & Trays & 25.99 & 129.95 \\
\hline 10 & Set cutlery & 45.99 & 459.90 \\
\hline & Subtotal & & 589.85 \\
\hline & VAT at $14 \% *$ & & 82.58 \\
\hline & Total & & 672.43 \\
\hline
\end{tabular}

Source: From first-year BEd Accounting, 2015, KwaZulu-Natal: Higher Education Institution VAT, value-added tax

"VAT at R589.85 × $0.14=$ R82.58 ( 82.579 and rounded up to nearest two decimals is R82.58). FIGURE 3: Credit invoice as an example of use of basic arithmetic operations. method algebra, as it shows how the formula is derived. They should be able to equate proportional fractions and solve for the variable or unknown (Method 1). They should also be able to recognise that the formula method is derived from the last but one step of the table method algebra. Knowledge of both methods will assist the student in verifying the answer if he or she has forgotten the formula or is not sure of the answer given by one method. The table method could assist in eradicating severe deficiencies in basic arithmetic skills.

For calculating profit mark-up percentage, consider the following example: Goods bought for R12 000 were sold for R17 400. Calculate the profit percentage (Figure 5).

\section{Ratios, rates and proportions}

Students must be able to differentiate between ratio, rate, and proportion. According to Mostyn (2008b), a ratio is a comparison of quantities by division or comparison of values (e.g. $5 \mathrm{~km}: 2 \mathrm{~L}$ of petrol). A rate is a ratio with different units in the numerator and denominator (e.g. $\frac{\mathrm{R} 20}{5 \text { units }}=\mathrm{R} 4$ per unit). A proportion is a statement that two ratios are equivalent. If one ratio is equal to another ratio, then equation 1 is called a proportion, for example:

$\begin{array}{ll}\frac{\mathrm{a}}{\mathrm{b}}=\frac{\mathrm{c}}{\mathrm{d}} & \text { proportional fractions equal } \\ \mathrm{ad}=\mathrm{bc} & \text { cross multiplication }\end{array}$

[Eqn 1]

Students must be able to calculate ratios by extracting appropriate information from financial statements. Financial statements analysis is conducted in the first-, second- and thirdyear modules. Therefore, students need to know and understand ratios. For students to understand the formula, they must be able to perform ratio analysis. Students must write a formula

\begin{tabular}{|ll|}
\hline Method 1 & Method 2 \\
$100 \%-10 \%=90 \%=0.90$ & Trade discount: \\
Therefore, R15000 $\sqrt{ } 0.90=\mathrm{R} 13500$ & R15 $000 \times 0.10=\mathrm{R} 1500$ \\
& Debt: \\
& R15 $000-\mathrm{R} 1500=\mathrm{R} 13500$ \\
\end{tabular}

FIGURE 4: Solution trade discount.

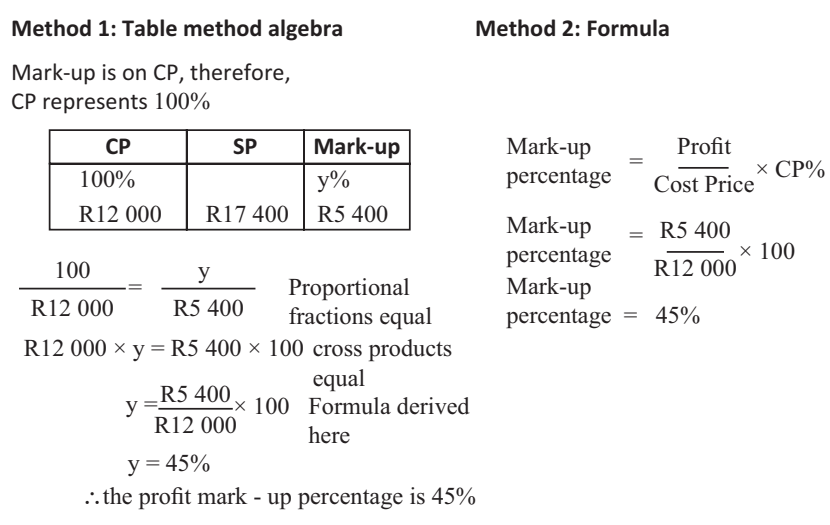

FIGURE 5: Solution profit percentage calculation. 
first, expand the formula (if there is a need), substitute the correct amounts and calculate. Examples of financial ratios are shown in Figure 6. Students should understand the logic of the calculation underlying the name of each financial indicator or ratio or rate. Students should not memorise the formulas as they can be easily forgotten if the underlying logic is not understood.

Students must be able to apportion insurance amount according to the percentages given for each of the given departments. Students must demonstrate an understanding of the split of costs between the factory, sales and office departments. Knowledge of fractions, ratios and percentages taught in Grades 8 and 9 and GET Mathematics is essential for splitting the costs between departments.

Example taken from third-year accounting is presented below - production concerns: Insurance R5600, electricity allocated between the factory, selling and distribution and administration as follows:

$\begin{array}{cccc} & \text { Factory } & \text { Sales } & \text { Office } \\ \text { Insurance } & 60 \% & 20 \% & 20 \%\end{array}$

Adjustment: R900 was paid in advance for insurance at the end of the year (Figure 7).

For ratios in distributing partners' profit, students must be able to distribute profit according to a specified ratio as it appears in the partnership agreement, beginning capital balance ratio, closing capital balance ratio or average capital balance ratio in months.

Consider the following example (third-year accounting), average capital balance ratio in months: The financial yearend of Edgewood Traders is 31 December each year. Capital: Edge(31/12/2015), R120 000 and Capital:Wood (31/12/2015), R150 000. Adjustment-additional capital by Edge (1/7/2015), R20 000 and cash withdrawal of capital by Wood (1/10/2015), R50 000.

Therefore, the profit sharing ratio according to average capital ratio is R110 000 : R137 500 (Figure 8).

For ratios in existing partners altering their profit sharing ratio (third-year accounting), students must be able to distribute profit according to the new ratio from the date of change (Figure 9). Consider the following example: Mrs Mthanti and Mrs Ngenywa, who share profits and losses in the ratio 3:2, decided to admit Mr Mtshali to the partnership on condition that he contributes one fourth of the partnership. Calculate the new profit sharing ratio.

Students must know that if the profit mark-up is on cost, then cost price represents $100 \%$. If the profit mark-up is on sales, then the selling price represents $100 \%$. Students need to calculate the cost of sales first in order to record the amount under cost of sales column in the cash receipts journal. They need to know both methods so that in case they forget the formula, they can revert to the table method, equate proportional fractions and solve for the unknown. The last

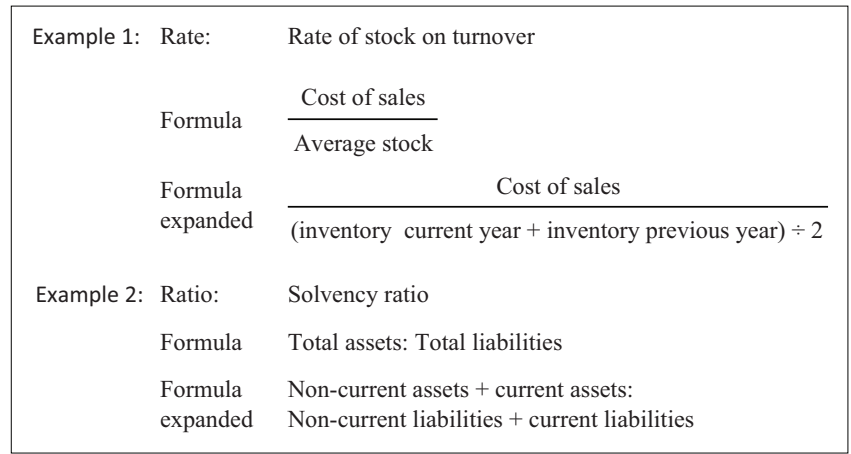

Source: From second-year BEd Accounting, 2015, KwaZulu-Natal: Higher Education Institution

FIGURE 6: Examples of financial ratios.

\begin{tabular}{|lllll|}
\hline Factory & $:$ & Sales & $:$ & Office \\
$4700 \times \frac{60}{100}$ & $:$ & $4700 \times \frac{20}{100}$ & $:$ & $4700 \times \frac{20}{100}$ \\
R 2820 & $:$ & R 940 & $:$ & R 940 \\
\hline
\end{tabular}

FIGURE 7: Allocation of amount according to given percentages.

Edgewood
$=\frac{\mathrm{R} 100000 \times 6 \text { months }+\mathrm{R} 120000 \times 6 \text { months }}{12 \text { months }}: \frac{\mathrm{R} 150000 \times 9 \text { months }+\mathrm{R} 100000 \times 3 \text { months }}{12 \text { months }}$
$=\mathrm{R} 110000: \mathrm{R} 137500$

Source: Third-year BEd Accounting, 2015, KwaZulu-Natal: Higher Education Institution FIGURE 8: Average capital balance ratio in months.

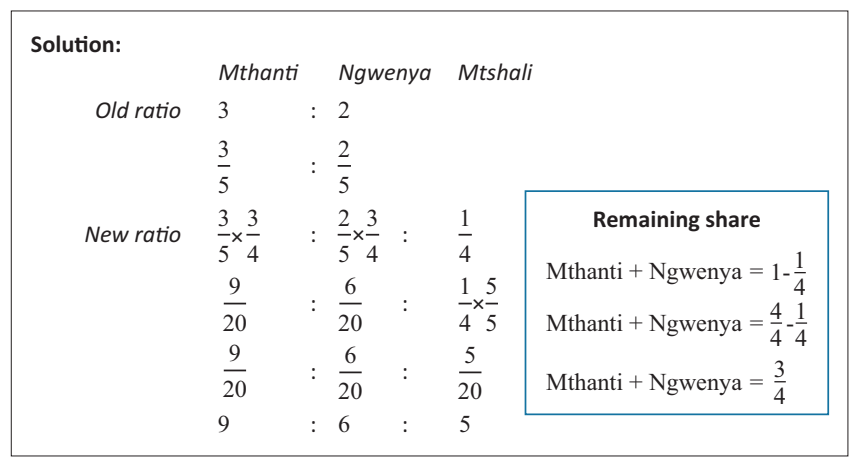

FIGURE 9: New profit sharing ratio. From third-year BEd Accounting.

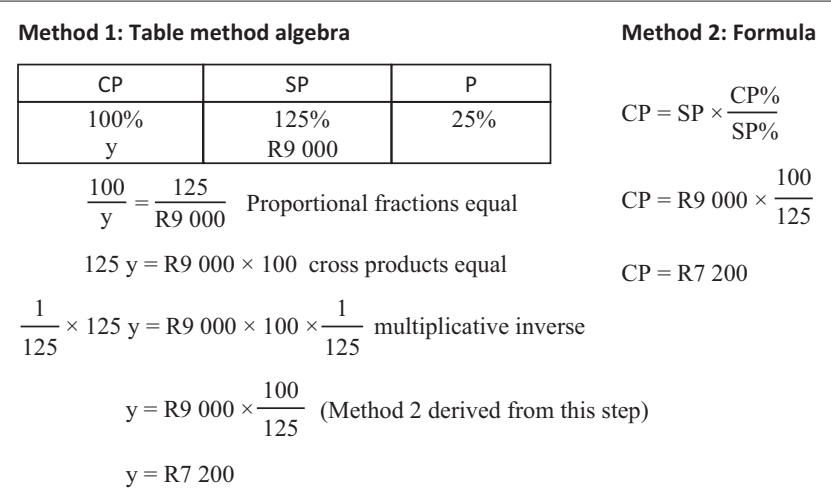

FIGURE 10: Cost price calculation. 


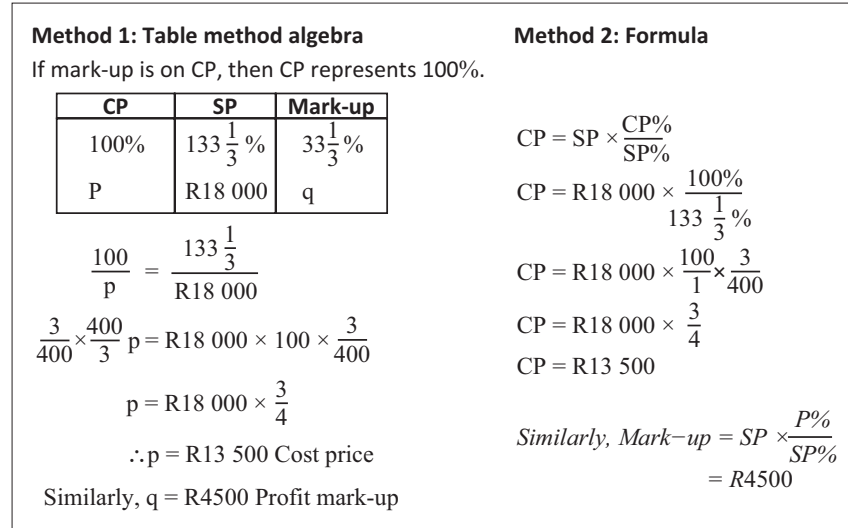

FIGURE 11: Cost of sales calculation given a mixed fraction percentage.

BOX 1: General ledger.

\begin{tabular}{|lrr|}
\hline Dr Branch stock account & R13 500 Dr Branch stock account & R 4500 \\
Cr Goods-sent-to-branch account & R13 500 Cr Branch adjustment account & R 4500
\end{tabular}

but one step of the table method shows the formula that the student must know and understand (Figure 10). Consider the following example: Sold goods for cash, R9 000 (Profit mark-up $25 \%$ on cost).

Proportional fractions involving mixed fractions. Consider the following example from Branch accounting: Goods are supplied to the branch at selling price (cost price plus $33 \frac{1}{3} \%$. Goods delivered to the branch is R18000. Calculate the amount to be recorded in Branch stock account, branch adjustment account and goods-sent-to-branch account (Figure 11).

Students need to calculate first, before recording the journal entries and posting to general ledger (see box 1).

\section{Patterns and algebra}

\section{Formulas (substituting and changing subject of formula)}

Students must know that at break-even point there is no profit or loss. If the production is less (more) than break-even point, it means there is loss (profit). Students must be able to work backwards to calculate the missing amount. It is also important that students first understand the calculation of unit costs and break-even point so that they can quote it to substantiate their comment when required. Students must be able to substitute from the relevant formula and solve by making the unknown the subject of the formula. Consider the following example from third-year accounting (Figure 12):

As shown in Figure 12, students must know each step and its formula. This will assist them to tackle a break-even point problem at any point of the steps indicated above. They must also know that they could be given the selling price per unit and each variable cost per unit (see Step 2 above). The students must therefore use Equation 2:

$\mathrm{BEP}=$

Total fixed costs

Selling price per unit - (Direct material cost per unit + Direct labour cost per unit + Distribution cost)

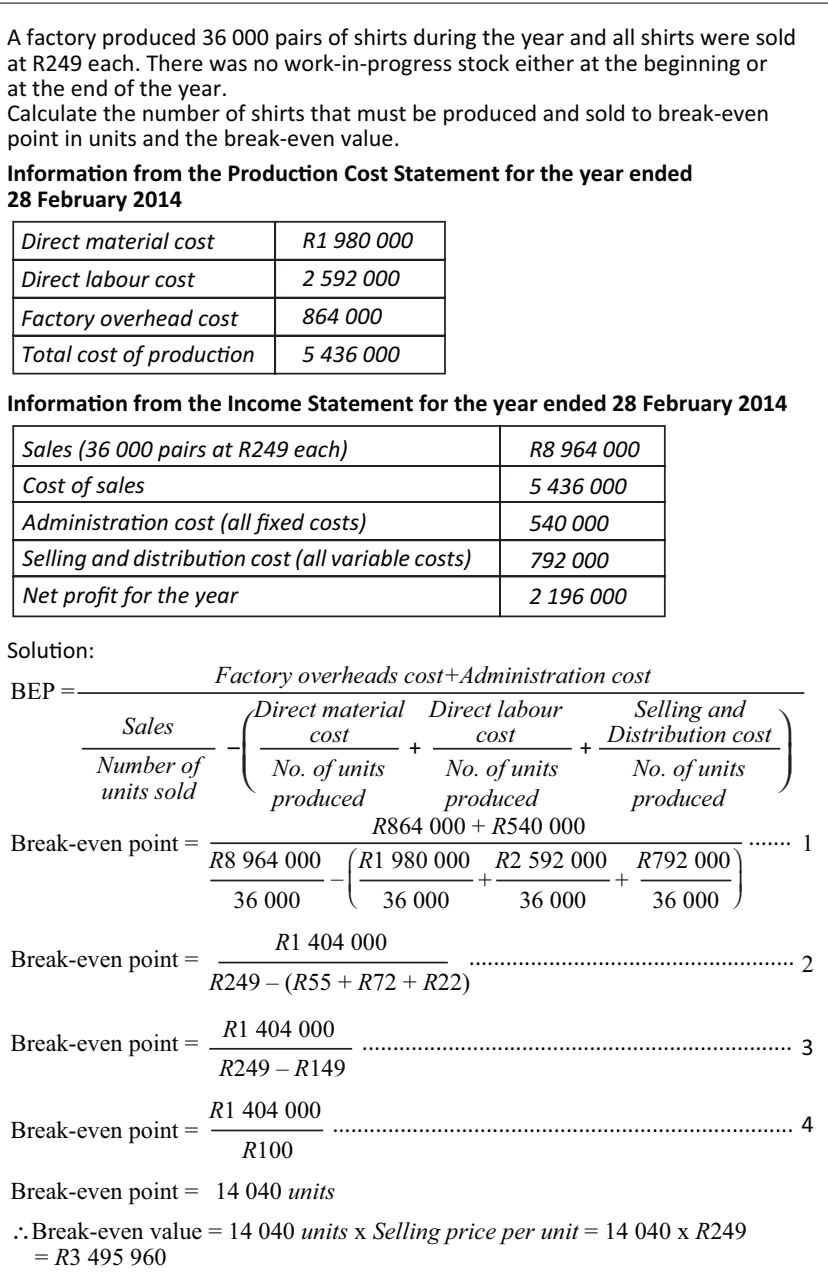

FIGURE 12: Break-even point in units and value calculation.

[Eqn 2]

Students must also know that they could be given total variable costs. See Step 3 above and Equation 3:

\section{$\mathrm{BEP}=\frac{\text { Total fixed costs }}{\text { Selling price per unit }- \text { Total variable cost per unit }}$}

Students could also be given contribution cost per unit. See Step 4 above and the formula below.

$$
\mathrm{BEP}=\frac{\text { Total fixed costs }}{\text { Contribution cost per unit }}
$$

\section{Algebraic equations (linear)}

Students' understanding of linear equations is important. They need to be able to form linear equations and solve for the missing amount. They must be able to form two algebraic expressions and equate them. They must apply mathematical concepts such as distributive law; transposing constants, variables and changing signs (additive inverse); and multiplying by multiplicative inverse of the coefficient of variable. In addition, they must be able to check the solution by substituting the answer to the original equation. If the lefthand side is equal to the right-hand side, then the solution is correct or valid, provided the equation formed is correct. By the end of Grade 9, students should have covered algebraic 
BOX 2: Third-year accounting.

$\begin{array}{lll}\text { Edgewood Traders (Extract) } & & \\ \text { Pre- Adjustment Trial Balance on 31 December 2015 } & & 140000 \\ \text { Profit and loss } & 65000 & \\ \text { Interest on capital: J. James } & 30,00 & \\ \text { Interest on capital: P Pule } & ? & \end{array}$

equations. The example in Box 2 from third-year accounting illustrates what type of calculation students must be able to perform, given the relevant information.

Partnership agreement: Partner, J. James, is entitled to a commission of $20 \%$ of the net profit after his interest on capital and his own commission has been taken into account (Figure 13).

Accounting equation: I will set this out at length as I feel it is important and is often a challenge for students. Equations in accounting are called accounting equations or balance sheet equations, where Assets = Owners' equity + Liabilities is a mathematical representation derived from the traditional balance sheet or statement of financial position, with assets on the left-hand side and owners' equity and liabilities on the right-hand side. Students must know the role of the equal sign on the equation. They must realise that this is part of a mathematical equation. Therefore, they must be able to link between the mathematical equation covered in a mathematics class and the accounting equation covered in accounting. Students must be able to transfer the knowledge and skills learnt in the mathematics class to the accounting class. They need to be able to derive, understand and apply basic accounting rules and be able to record the correct signs and amounts on the elements of the accounting equation (Figure 14).

In the basic accounting equation (Eqn 4) or balance sheet equation:

$$
\mathrm{A}=\mathrm{O}+\mathrm{L}
$$

where $\mathrm{A}=$ Assets, $\mathrm{O}=$ Owners' equity and $\mathrm{L}=$ Liabilities.

Students must know that the original accounting equation, $\mathrm{A}=\mathrm{O}+\mathrm{L}$, can also be written as follows:

- by making $\mathrm{O}$ the subject of the formula, $\mathrm{O}=\mathrm{A}-\mathrm{L}$

- by making $\mathrm{L}$ the subject of the formula, $\mathrm{L}=\mathrm{A}-\mathrm{O}$.

Students must know that the process of conceptualising and understanding the basic accounting equation rules requires the understanding of mathematical equations. From the equation $\mathrm{A}=\mathrm{O}+\mathrm{L}$ the basic accounting rules are derived (see Box 3 ).

Mathematical explanation for derivation of the basic accounting equation rules:

Asset $(A)$ rule. From the equation $\mathrm{A}=\mathrm{O}+\mathrm{L}$, if you transpose A to the right-hand side, then the sign changes to negative. Therefore, we get $-\mathrm{A}$.

Owners' equity $(\mathrm{O})$ rule. From the equation $\mathrm{A}=\mathrm{O}+\mathrm{L}$, if you transpose $\mathrm{O}$ to the left-hand side, then the sign changes to negative. Therefore, we get $-\mathrm{O}$. Students must remember that final accounts or income statement items form part of owners' equity.

$$
\begin{aligned}
& \text { Let the commission be } \mathrm{y} \text {. } \\
& \qquad \begin{aligned}
\mathrm{y} & =20 \%(\text { Net profit-Interest on capital }-\mathrm{y}) \\
\mathrm{y} & =0.20(140000-65000-\mathrm{y}) \\
\mathrm{y} & =15000-0.20 \mathrm{y} \\
1.20 \mathrm{y} & =15000 \\
\mathrm{y} & =\frac{15000}{1.20} \\
\mathrm{y} & =12500 \\
& \therefore \text { Commission is R12 } 500
\end{aligned}
\end{aligned}
$$

FIGURE 13: Commission calculation using linear equation method.

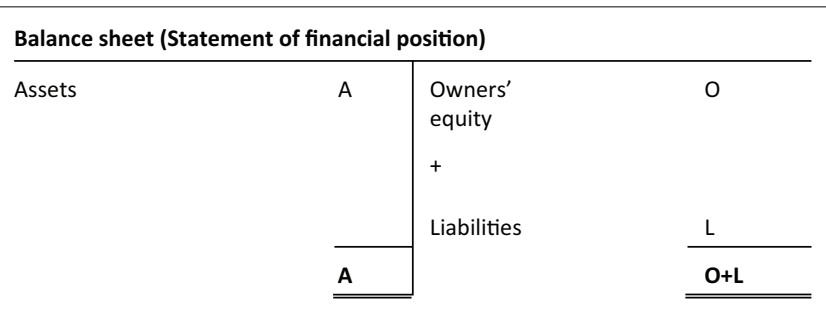

Source: First-year BEd Accounting, 2015, KwaZulu-Natal: Higher Education Institution FIGURE 14: Statement of financial position.

BOX 3: Basic accounting rules.

\begin{tabular}{|l|l|l|l|}
\hline \multicolumn{2}{|c|}{$\mathrm{A}$} & \multicolumn{2}{|c|}{$\mathrm{L}$} \\
\hline+ & - & + & + \\
\end{tabular}

\begin{tabular}{|lllclc|}
\hline Solution: & & & & & \\
& Assets & $=$ & Owner's equity & + & Liabilities \\
Transaction 1 & +95000 & $=$ & +95000 & + & 0 \\
Transaction 2 & +12000 & $=$ & 0 & + & +12000
\end{tabular}

FIGURE 15: Basic accounting equation solution.

Liabilities $(L)$ rule. From the equation $\mathrm{A}=\mathrm{O}+\mathrm{L}$, if you transpose $\mathrm{L}$ to the left-hand side, then the sign changes to negative. Therefore, we get $-\mathrm{L}$.

Without understanding the mathematical reasoning of basic accounting equation rules, students might find themselves simply memorising the rules. If they understand the mathematical reasoning of these rules, they are less likely to be intimidated by tasks or activities that require the application of these rules. Consider the following example of basic accounting equation solution from first-year accounting.

Transaction 1: Basic accounting equation, M. Mkhize, Edgewood Traders owner deposited R 95000 in the bank account of the business as his capital contribution.

Transaction 2: Bought merchandise on account from Jeena Wholesalers, R 12000 (Figure 15).

\section{Mathematical modelling (creating mathematical formulas} or equations from real-life context or word problem)

Students need a confident understanding of mathematical modelling. Understanding will be gained if they have had a great deal of exposure to working with accounting activities involving mathematical modelling. Students must not be intimidated by this type of adjustment, which requires an 
understanding of mathematical skills such as deriving timeline, forming and solving equations, checking answer from the original equation or using the formula to verify the answer.

Consider the following examples from first-year accounting. Adjusting rent given a percentage increase. Pre-adjustment Trial Balance on 31 December 2015 (Extract):

\begin{tabular}{|c|c|}
\hline & Debit \\
\hline Rent income & \\
\hline
\end{tabular}

Rent increased by $10 \%$ on 01 July 2015 and has been received for 13 months (Figure 16, Boxes 4, 5, 6, 7).

Students must be able to differentiate between a rent percentage decrease and increase. The example below involves adjusting rent given a percentage decrease.

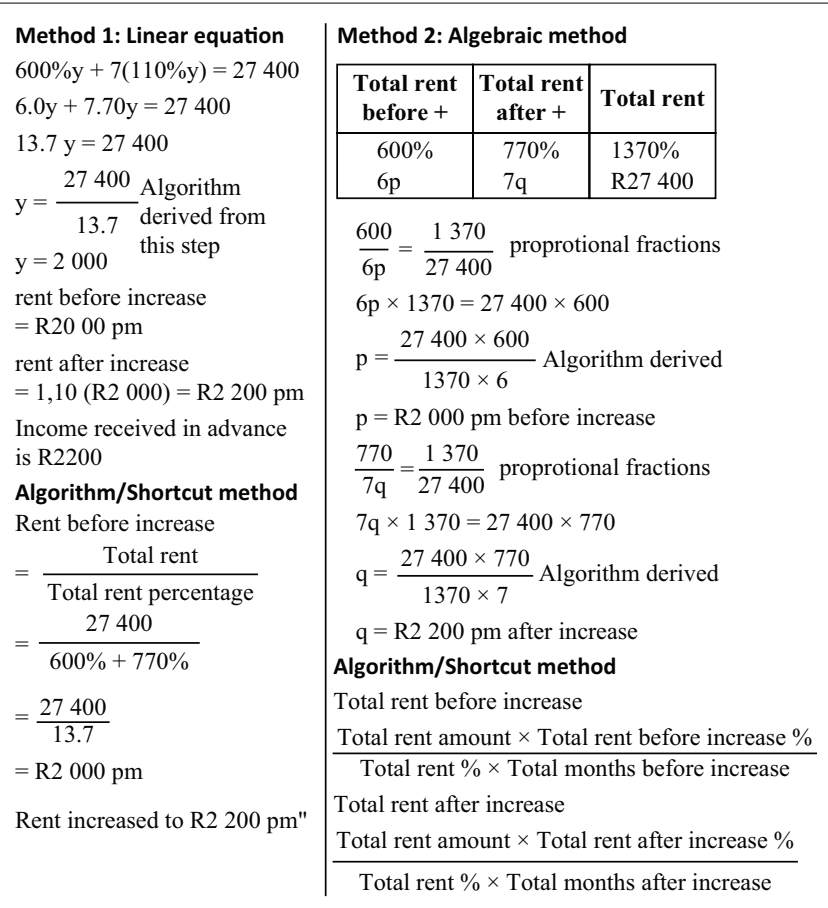

FIGURE 16: Rent calculation, given increase in percentage.
Rent - given a percentage decrease: Adjusting rent given a percentage decrease. Pre-adjustment Trial Balance on 31 December 2014 (Extract):

\section{Debit Credit}

Rent income

Rent decreased by $10 \%$ on 01 July 2014 and has been received for 13 months. Therefore, timelines are given a percentage decrease.

By following the algebraic and algorithm methods shown in Figure 16, students must be able to calculate that the rent before increase is R500 and the rent after decrease is R500 × $\mathrm{R} 0.90$ = R450.

Rent - given an increase by amount: Students must be able to adjust rent amount if given an increase or decrease in amount. Consider the following example from second-year accounting: Pre-adjustment trial balance on 31 December 2015:

Debit

Credit

Rent income

27400

Rent increased on 01 July 2015 by R200 per month and has been received for 13 months (Figure 17).

Timeline and calculations, given increase by amount. Rent given a decrease by amount: Students must be able to form an equation and solve it if rent decreased by an amount per month, and know that the algorithm or shortcut for the decrease in rent amount per month is (see Equation 5):

Rent before decrease $=\frac{\text { Total rent }+ \text { total increase }}{\text { No } \text { of months }} \quad$ [Eqn 5]

Algebraic equations in value-added tax (VAT) calculation Students must be able to prepare or create a VAT table and equate proportional fractions and solve for the unknown. They must also be able to derive the formula (Method 2) from the last but one step of the algebraic equation (Method 1). They need to know the algebraic method in order to verify

BOX 4: Timeline for Method 1: Let the rent be $y$.

\begin{tabular}{|c|c|c|c|c|c|c|c|c|c|c|c|c|}
\hline $\mathrm{J}$ & $\mathrm{F}$ & $M$ & A & $M$ & $\mathrm{~J}$ & $\mathrm{~J}$ & A & $S$ & 0 & $\mathrm{~N}$ & D & $\mathrm{J}$ \\
\hline $100 \% y$ & $100 \% y$ & $100 \% y$ & $100 \% y$ & $100 \% y$ & $100 \% y$ & $110 \% y$ & $110 \% y$ & $110 \% y$ & $110 \% y$ & $110 \% y$ & $110 \% y$ & $110 \% y$ \\
\hline
\end{tabular}

BOX 5: Timeline for Method 2: Let the rent before increase be $p$ and let the rent after increase be $q$

\begin{tabular}{|c|c|c|c|c|c|c|c|c|c|c|c|c|}
\hline $\mathrm{J}$ & $\mathrm{F}$ & $M$ & $A$ & $M$ & $\mathrm{~J}$ & $\mathrm{~J}$ & $A$ & $\mathrm{~S}$ & 0 & $\mathrm{~N}$ & D & $\mathrm{J}$ \\
\hline $100 \%$ & $100 \%$ & $100 \%$ & $100 \%$ & $100 \%$ & $100 \%$ & $110 \%$ & $110 \%$ & $110 \%$ & $110 \%$ & $110 \%$ & $110 \%$ & $110 \%$ \\
\hline$p$ & $p$ & $p$ & $p$ & $p$ & $p$ & $q$ & $q$ & $q$ & $q$ & $Q$ & $q$ & $q$ \\
\hline
\end{tabular}

BoX 6: Timeline for Method 1: Let the rent be $y$.

\begin{tabular}{|c|c|c|c|c|c|c|c|c|c|c|c|c|}
\hline J & $\mathrm{F}$ & $M$ & A & $M$ & J & J & A & $S$ & 0 & $\mathrm{~N}$ & D & J \\
\hline $100 \% y$ & $100 \% y$ & $100 \% y$ & $100 \% y$ & $100 \% y$ & $100 \% y$ & $90 \% y$ & $90 \% y$ & $90 \% y$ & $90 \% y$ & $90 \% y$ & $90 \% y$ & $90 \% y$ \\
\hline
\end{tabular}

BOX 7: Timeline for Method 2: Let the rent before decrease be $p$ and let the rent after decrease be $q$.

\begin{tabular}{|c|c|c|c|c|c|c|c|c|c|c|c|c|}
\hline $\mathrm{J}$ & $\mathrm{F}$ & $M$ & A & $M$ & $\mathrm{~J}$ & $\mathrm{~J}$ & A & $S$ & 0 & $\mathrm{~N}$ & D & $\mathrm{J}$ \\
\hline $100 \%$ & $100 \%$ & $100 \%$ & $100 \%$ & $100 \%$ & $100 \%$ & $90 \%$ & $90 \%$ & $90 \%$ & $90 \%$ & $90 \%$ & $90 \%$ & $90 \%$ \\
\hline$P$ & $p$ & $p$ & $p$ & $p$ & $P$ & $q$ & $q$ & $q$ & $q$ & $q$ & $q$ & $q$ \\
\hline
\end{tabular}


BOX 8: Timeline: Let the rent before increase be $\mathbf{p}$ and that after increase be $p+200$.

\begin{tabular}{|c|c|c|c|c|c|c|c|c|c|c|c|c|}
\hline $\mathrm{J}$ & $\mathrm{F}$ & $M$ & A & $M$ & $\mathrm{~J}$ & $\mathrm{~J}$ & A & $\mathrm{S}$ & 0 & $N$ & D & $\mathrm{J}$ \\
\hline$p$ & $p$ & $p$ & $p$ & $p$ & $P$ & $p+200$ & $p+200$ & $p+200$ & $p+200$ & $p+200$ & $p+200$ & $p+200$ \\
\hline
\end{tabular}

\begin{tabular}{|c|c|}
\hline Method 1: Linear equation & Method 2: Algorithm/shortcut \\
\hline \multicolumn{2}{|l|}{$6 p+7 p+1400=27400$} \\
\hline $13 p+1400=27400$ & $\begin{array}{c}\text { Rent before } \\
\text { increase }\end{array}=\frac{\text { Tota lrent } \text { - total increase }}{\text { No of months }}$ \\
\hline $13 p=27400-1400$ & Increase $27400-1400$ \\
\hline$p=\frac{27400-1400}{13}$ & $=\frac{2 / 400-1400}{13}$ \\
\hline $\mathrm{p}=2000$ & increase \\
\hline $\begin{array}{l}\mathrm{R} 2000 \mathrm{pm} \text { rent before } \\
\text { increase }\end{array}$ & $\begin{aligned} \therefore & R 2200 \text { pm rent after } \\
& \text { increase }\end{aligned}$ \\
\hline $\begin{array}{l}\therefore \mathrm{R} 2200 \mathrm{pm} \text { rent after } \\
\text { increase }\end{array}$ & \\
\hline
\end{tabular}

FIGURE 17: Rent calculation given increase in amount.

\begin{tabular}{|c|c|c|c|}
\hline \multicolumn{3}{|c|}{ Method 1: Algebraic method } & \multirow{2}{*}{$\begin{array}{l}\text { Method 2: Algorithm/shortcut } \\
\text { VAT }=\mathrm{SP}(\text { Incl VAT }) \times \text { VAT } \%\end{array}$} \\
\hline $\begin{array}{l}\text { SP(Excl. } \\
\text { VAT) }\end{array}$ & $\begin{array}{l}\text { SP } \\
\text { (Incl. VAT) }\end{array}$ & VAT & \\
\hline $100 \%$ & $\begin{array}{l}114 \% \\
\text { R141930 }\end{array}$ & $\begin{array}{l}14 \% \\
\mathrm{P}\end{array}$ & $\begin{aligned} \text { VAT } & =\mathrm{SP}(\text { Incl } V \mathrm{AT}) \times \overline{\mathrm{SP}(\text { incl. VAT })} \% \\
& =\mathrm{R} 141930 \times \frac{14 \%}{1140}\end{aligned}$ \\
\hline$\frac{114}{\mathrm{R} 141930}=$ & \multicolumn{2}{|c|}{ Proportional fractions } & $=\mathrm{R} 17430$ \\
\hline \multicolumn{2}{|c|}{$114 p=R 141930 \times 14$} & \multicolumn{2}{|c|}{ Cross multiply } \\
\hline \multicolumn{2}{|c|}{$\mathrm{p}=\underline{\mathrm{R} 141930 \times 14}$} & \multicolumn{2}{|c|}{ Method 2 derived here } \\
\hline & 430 & & \\
\hline
\end{tabular}

FIGURE 18: Value-added tax calculation.

the answer. If they have forgotten the formula, they need to consider the VAT example. They should also understand the problem and apply the mathematical principles relevant to equations, percentages, fractions, proportions and basic operations. These are covered in GET Mathematics Grades 8 and 9 levels before students select mathematics or Mathematical Literacy in Grade 10. Calculating VAT in terms of the table method assists students in understanding when to use a calculation involving $\frac{14}{100}$ if given selling price excluding VAT, and $\frac{14}{100}$ if given the selling price including credit sales (including VAT) amount to R141 930. Calculate VAT (Figure 18).

\section{Number patterns (sequences and series)}

Depreciation is the sum-of-the-digits method. Consider the following example:

$\begin{array}{lrr}\text { Plant (at cost) } & \text { Debit } & \text { Credit } \\ & 110000 & \\ \text { Accumulated depreciation on plant } & & 38000\end{array}$

Adjustment and additional information: Depreciation must be written off on plant in its third-year, over 10 years, using the sum-of-the-digits method (Figure 19).

Students must be able to form a series in descending order and get the sum of all digits. To get the depreciation, they must know that one has to consider the year and divide by the sum-of-the-years digits and multiply by the cost of an asset without being confused when performing this type of depreciation method.

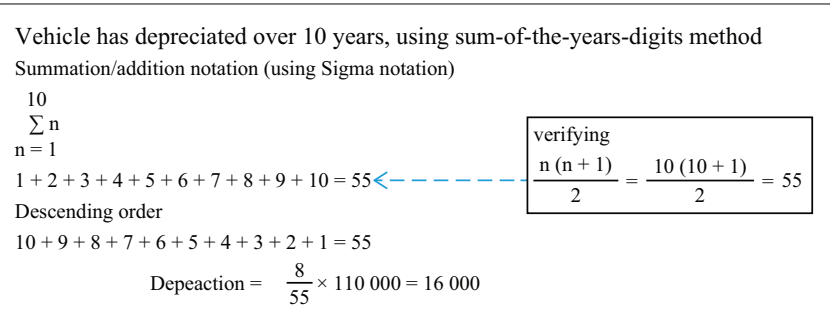

FIGURE 19: Sum-of-the-years-digits method.

\section{Tables}

Students should be able to read financial information from given tables and follow instructions. They must also prepare tables and perform calculations as well as record amounts and details in the appropriate given table columns.

\section{Financial mathematics}

In this section, I will show that in financial mathematics there is a clear link that transfers across to accounting, as in formulas, exponents and substitution. This aspect is also referred to as time value of money because money has value over time. If you invest, you must be compensated for waiting or taking risk. All BEd Accounting students must know financial mathematics formulas. They must remember each of these formulas and be able to substitute values into the formulas, and they must also know how to change the subject of the formula. They must use the calculator to perform the calculation and have knowledge of calculations involving exponents. They must know how to apply the brackets of multiplication, division, addition and subtraction (BOMDAS) or brackets of division, multiplication, addition and subtraction (BODMAS) rule. Students must also know the exponential rules, such as Equation 6.

$y^{1}=y, \frac{1}{y^{n}}=y^{-n}$ and $y^{\frac{p}{q}}=\sqrt[q]{y^{p}}$.

[Eqn 6]

Simple and compound interest: Students need to know the simple interest formula and substitute values as well as make $P$ or $r$ or $I$ subject of the formula. As shown in Figure 20, simple interest formulas used in mathematics are also used in accounting.

Simple interest: Equation 7 is used for calculating simple interest.

Formula

$$
i=P \times \frac{r}{100} \times \frac{t}{12}
$$

where $i=$ interest, $P=$ principal amount initially invested or loaned, $r=$ rate of interest and $t=$ term or time of the investment or loan in months. 


\begin{tabular}{|c|c|c|}
\hline FORMULA & MATHEMATICS & ACCOUNTING \\
\hline Simple interest (i) & $\mathrm{i}=\mathrm{P} \times \frac{\mathrm{r}}{100} \times \frac{\mathrm{t}}{12}$ & $\mathrm{i}=\mathrm{P} \times \frac{\mathrm{r}}{100} \times \frac{\mathrm{t}}{12}$ \\
\hline $\begin{array}{l}\text { Making } \mathbf{P} \text { the subject of the } \\
\text { formula }\end{array}$ & $P=i \times \frac{100}{r} \times \frac{12}{t}$ & $P=i \times \frac{100}{r} \times \frac{12}{t}$ \\
\hline $\begin{array}{l}\text { Making } \mathbf{r} \text { the subject of the } \\
\text { formula }\end{array}$ & $r=\frac{i}{P} \times \frac{12}{t} \times \frac{100}{1}$ & $\mathrm{r}=\frac{\mathrm{i}}{\mathrm{P}} \times \frac{12}{\mathrm{t}} \times \frac{100}{1}$ \\
\hline $\begin{array}{l}\text { Making } \mathbf{t} \text { the subject of the } \\
\text { formula }\end{array}$ & $t=\frac{i}{P} \times \frac{12}{1} \times \frac{100}{r}$ & $t=\frac{i}{P} \times \frac{12}{1} \times \frac{100}{r}$ \\
\hline
\end{tabular}

FIGURE 20: Simple interest - Mathematics versus accounting.

\begin{tabular}{|c|c|c|}
\hline \multirow[t]{2}{*}{ FORMULA } & MATHEMATICS & ACCOUNTING \\
\hline & & $\mathrm{n}=1$ year, multiply $\mathrm{r}$ by $\frac{\mathrm{t}}{12}$ \\
\hline Compound interest & $\mathrm{A}=\mathrm{P}\left(1+\frac{\mathrm{r}}{100}\right)^{\mathrm{n}}$ & $\mathrm{A}=\mathrm{P}\left(1+\frac{\mathrm{r}}{100} \times \frac{\mathrm{t}}{12}\right)^{\mathrm{n}}$ \\
\hline \multirow{3}{*}{$\begin{array}{l}\text { Making } \mathrm{P} \text { the subject } \\
\text { of the formula }\end{array}$} & A & \multirow{2}{*}{$\mathrm{P}=\frac{\mathrm{A}}{\left(1+\frac{\mathrm{r}}{100} \times \frac{\mathrm{t}}{12}\right)^{\mathrm{n}}}$} \\
\hline & $\left(1+\frac{\mathrm{r}}{100}\right)^{\mathrm{n}}$ & \\
\hline & $\mathrm{P}=\mathrm{A}(1+\mathrm{r})^{-\mathrm{n}}$ & $\mathrm{P}=\mathrm{A}\left(1+\frac{\mathrm{r}}{100} \times \frac{\mathrm{t}}{12}\right)^{-\mathrm{n}}$ \\
\hline $\begin{array}{l}\text { Making } r \text { the subject } \\
\text { of the formula }\end{array}$ & $r=\left[\left(\frac{A}{P}\right)^{\frac{1}{n}}-1\right] \times \frac{100}{1}$ & $r=\left[\left(\frac{A}{p}\right)^{\frac{1}{n}}-1\right] \times \frac{1200}{t}$ \\
\hline Making $\mathrm{n}$ the subject & $\log \frac{A}{P}$ & $\log \frac{\mathrm{A}}{\mathrm{P}}$ \\
\hline & $\log \left(1+\frac{r}{100}\right)$ & $\log \left(1+\frac{r}{100} \times \frac{t}{12}\right)$ \\
\hline
\end{tabular}

FIGURE 21: Compound interest - Mathematics versus accounting.

Compound interest: Equation 8 is used for calculating compound interest.

$\mathrm{A}=p\left(1+\frac{r}{100}\right)^{n}$

where $\mathrm{A}=$ amount received at the end of investment period, $P=$ principal, $r=$ compounded annual interest rate and $n=$ number of years.

Students need to know the compound interest formula and how to make the subject of the formula and apply the formula to relevant accounting problems. As shown in Figure 21, in mathematics, future value (amount) of an investment could be calculated; so $n$ could be 1 year or more. In accounting, the accrual concept says income and expenses must be recognised in the financial year $(n=1$ year) in which they relate.

Students must know exponential rules. Knowing and understanding exponential rules will help students in applying formulas with exponents. The student must know that the accounting period is 1 year. Therefore, $n=1$ (see example in Table 4). They must be able to substitute from the formula, as shown in Figure 22.

Students must know and understand logarithms rules which will help them in using the formula involving logarithms. They must also know how to substitute from the formula and perform the calculation. Figure 23 illustrates a step-by-step process of calculation that students must be able to perform.
TABLE 4: Extract from Cash budget of Edgewood Ltd for January and February 2012.

\begin{tabular}{|c|c|c|}
\hline Cash payments & January & February \\
\hline Repayment of loan & 0 & 120000 \\
\hline Interest on loan & 5000 & $?$ \\
\hline \multicolumn{3}{|c|}{$\begin{array}{l}\text { Note: Additional information: Loan received on } 31 \text { December } 2010 \text { is R300 000. Interest is } \\
\text { paid monthly by cheque. }\end{array}$} \\
\hline \multicolumn{3}{|c|}{ From Compound interest formula ( $r$ subject of the formula) } \\
\hline & $r=$ & \\
\hline & $r=$ & $\frac{1200}{1}$ \\
\hline & $r=2$ & \\
\hline
\end{tabular}

FIGURE 22: Calculating rate of interest.

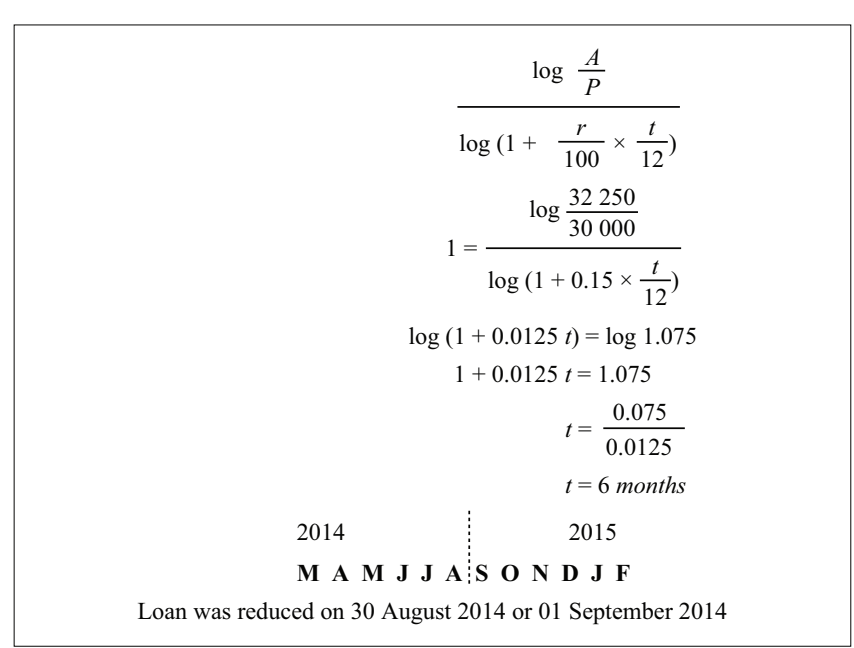

FIGURE 23: Date on which the loan was reduced.

Extract from the Statement of financial position of Edgewood Traders. Accounting period ends on 28 February each year:

$\begin{array}{llrr} & & 2015 & 2014 \\ \text { Non-current liabilities } & (15 \%) & \text { R50 000 } & \text { R80 000 } \\ \text { Interest on loan } & & 9750 & 12000\end{array}$

Calculate the date on which the loan was reduced.

Using the formula involving logarithms (from compound interest formula, $\mathrm{n}$ made subject of the formula, as shown in Figure 23).

The Equation 9 is used for calculating simple interest:

Formula

$$
n=\frac{\log \frac{\mathrm{A}}{\mathrm{P}}}{\log \left(1+\frac{r}{100} \times \frac{t}{12}\right)}
$$

where $n=$ accounting period ( 1 year), $\mathrm{P}=$ principal amount initially invested or loaned, $r=$ rate of interest and $t=$ term or time of the investment or loan in months.

Simple versus compound depreciation: The purpose of this section is to show that simple and compound interest formulas are used to calculate depreciation, but the sign changes (positive to negative) when calculating depreciation. 
Simple and compound depreciation methods are used for both cost price and diminishing balance methods. Accounting students are required to know these formulas for cost price and diminishing depreciation methods in order to be able to perform depreciation calculation when given different values. Students must be able to substitute into formulas and know how to change the subject of the formula. Students must use a calculator to perform the calculation and have knowledge of calculations involving exponents. Cost price (straight line or flat rate) method.

Simple depreciation: Equation 10 is used for calculating simple depreciation:

$$
d=C P \times \frac{r}{100} \times \frac{t}{12}
$$

where $d=$ depreciation for the financial year, $C P=$ the cost price of an asset, $r=$ the depreciation rate per year and $t=$ term or time in months.

Compound depreciation: Equation 11 is used for calculating compound depreciation:

$$
\begin{aligned}
& B V=C P\left(1-\frac{r}{100} \times \frac{t}{12}\right)^{n} \ldots \ldots \ldots . . .1 \\
& d=C P-B V \ldots \ldots \ldots .2
\end{aligned}
$$

where $n=1$ year (accounting period).

Students must be able to apply the above formulas to different depreciation calculations. They must also be able to calculate depreciation of tangible asset, if acquired, during the year.

Diminishing balance (reducing balance or book value or carrying value) method

Simple depreciation: Equation 12 is used for calculating simple depreciation:

$$
d=(C P-A D) \times \frac{r}{100} \times \frac{t}{12}
$$

where $d=$ depreciation for the financial year, $C P=$ the cost price of an asset, $A D=$ accumulated depreciation of an asset, $C P-A D=$ book value at the beginning of the year, $r=$ depreciation rate per year and $t=$ term or time in months.

This formula is frequently used by students because it gives depreciation without performing a lot of steps. Students must know that one has to first reduce accumulated depreciation from the cost price of an asset (book value of an asset beginning of the financial year) before multiplying by rate $(r)$ and time $(t)$.
Compound depreciation: Students must employ mathematical reasoning when they calculate using different types of simple interest and compound formulas (see Equations 12 and 13). To master these calculations they need a lot of practice, which will help to alleviate intimidation that may be caused by a lot of formulas. Students must know that table method algebra could be used to solve simple and compound depreciation accounting problems:

$B V_{e y}=C P-A D\left(1-\frac{r}{100} \times \frac{t}{12}\right)^{n}$

where: $n=1$ year (accounting period)

In Equation 14, $B V_{e y}=$ book value at the end of the financial year, $\mathrm{CP}=$ the cost price of an asset, $\mathrm{AD}=$ accumulated depreciation of an asset, $C P-A D=$ book value at the beginning of the financial year, $r=$ depreciation rate per year, $t=$ term or time in months:

$\therefore d=B V_{b y}-B V_{e y}$

[Eqn 14]

In Equation 13, $d=$ depreciation, $\mathrm{BV}_{\mathrm{ey}}=$ Book value at the beginning of the financial year and $\mathrm{BV}_{\mathrm{ey}}=$ book value at the end of the financial year.

Students must be able to use the above formulas for different depreciation calculation activities. They must also be able to calculate deprecation of fixed assets acquired during the financial year, as shown in Figure 24:

Extract: Pre-adjustment trial balance of Edgewood Traders on 28 February 2013 (EDAC210EC)

Debit Credit

Vehicles (at cost) 210000

Accumulated depreciation on vehicles 17100

\section{Adjustment and additional information}

Provide depreciation on vehicles at $15 \%$ per annum on the diminished balance method. (Take into account that a new vehicle was bought on 01 December 2012 for R120 000).

\section{Statistics (data handling and probability) Average and weighted average}

In the case of the average, students need to understand how to calculate an average, an arithmetic mean (average $=[\mathrm{R} 30+$ R20] / 2 = R25), and weighted average, a method of computing a kind of an arithmetic mean of a set of numbers. Students must know that, to calculate a weighted average price of shares available, they must divide the total value of shares available by the number of shares available. It is important that students know and understand that to calculate the weighted average, they do not have to divide by two because the answer will be wrong. Therefore, they must know the difference between average and weighted average. In the case of weighted average price per share, students need to know 


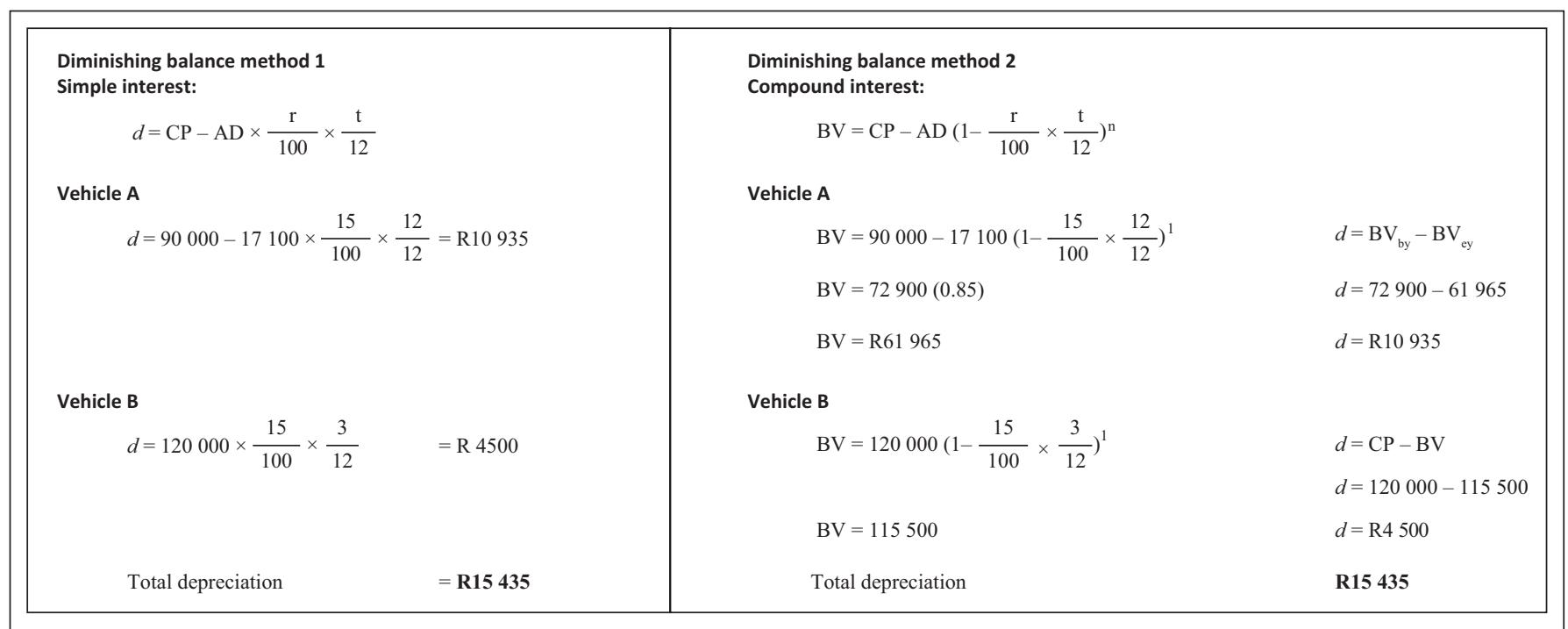

FIGURE 24: Diminishing balance method - Simple and compound interest.

$$
\begin{aligned}
& \text { Average share per price } \\
& \qquad \begin{aligned}
=\frac{\text { Total shares of value }}{\text { Total shares of number }} & =\frac{\mathrm{R} 800000+\mathrm{R} 1200000}{100000+100000} \\
& =\frac{\mathrm{R} 2000000}{200000} \\
& =\mathrm{R} 10 \text { per share }
\end{aligned}
\end{aligned}
$$

FIGURE 25: Method 1 formula - average price per share.

that calculating weighted average price per share is a prerequisite for answering the buyback of shares question. Consider the following example (from second-year accounting), where the buyback cost is higher than the average price per share:

Edgewood Ltd was established with an authorised share capital of R600000 ordinary shares. 200000 shares were issued to the public as follows: 100000 shares at R8 each and 100000 shares at R12 each. Transaction: 17 March 2013, Edgewood Ltd repurchased 10000 shares at a price of R12.50 per share (Figures $25 \& 26$ ).

For the weighted average price of inventory available, students need to know how to calculate the weighted average price of inventory available.

Students must know the formula and substitute the values from the formula. Students must know that the weighted average price of inventory available is multiplied by units on hand at the end of the financial year in order to get the value of closing inventory at the financial year if the business uses the periodic inventory system.

The value of closing stock according to the weighted average method is:

$=\mathrm{R} 502.08 \times 15$

$=\mathrm{R} 7531.20$

This amount will affect the calculation of gross profit in the trading account.

$$
\begin{aligned}
& \text { Weighted average price of inventory available } \\
& \begin{array}{l}
=\frac{\text { Total value of inventory available }}{\text { Total units of inventory available }} \\
=\frac{\mathrm{R} 7500+\mathrm{R} 12000-\mathrm{R} 1200+\mathrm{R} 8750+\mathrm{R} 9100}{15+20-2+25+14} \\
=\frac{\mathrm{R} 36150}{72} \\
=\mathrm{R} 502.08 \text { per bicycle }
\end{array}
\end{aligned}
$$

FIGURE 26: Formula - weighted average price of inventory available.

For both the weighted average price per share and stock available, students must demonstrate a systematic way of thinking (mathematical reasoning) and organising amounts given in calculating the weighted average price.

\section{Forecasting or projections}

Mathematics concepts such as statistics are used to forecast future cash flows based on several different scenarios. In second-year accounting, data handling and probabilities are used when preparing cash budgets and projections or forecasts (see example in Figure 27). Students must be able to calculate the variance by comparing the actual and budgeted figures to identify positive or negative variances before expressing opinions on variances. Students should be able to identify trends, for example to calculate percentage changes in the cash budget (Figure 28).

Students should be able to do calculations relevant to specific amounts in the cash budget for the cash sales and cash collected from debtors and payment to creditors. Therefore, debtors collection period and creditors payment schedule are important in knowing how to do workings or calculations. Not knowing what amounts or percentages to use may prevent students from getting correct answers to record in the cash budget. The students must know and understand concepts like decrease and increase. From projected income statement and the cash budget, they 


\begin{tabular}{|c|c|c|c|c|c|}
\hline \multicolumn{6}{|l|}{ Extract } \\
\hline \multicolumn{6}{|l|}{ Cash Budget 2015} \\
\hline & January & February & & January & February \\
\hline Cash Receipts & & & Cash Payments & & \\
\hline Cash sales & 41250 & A & Cash Purchases & $\mathrm{C}$ & 17500 \\
\hline Cash from debtors & $\mathrm{B}$ & 90125 & Payments to creditors & 66500 & $\mathrm{D}$ \\
\hline Sales & Actual & Budgeted & \multicolumn{3}{|c|}{ Amounts owed by debtors are collected as follows: } \\
\hline November & 125000 & & \multicolumn{3}{|c|}{$30 \%$ is paid during same month } \\
\hline December & 150000 & & \multicolumn{3}{|c|}{$50 \%$ is paid after 30 days (next month) } \\
\hline January & & 137500 & \multicolumn{3}{|c|}{$15 \%$ is paid after 60 days ( 2 months) } \\
\hline February & & 125000 & \multirow{2}{*}{\multicolumn{3}{|c|}{$5 \%$ is written off after 90 days ( 3 months) }} \\
\hline \multicolumn{3}{|c|}{ Credit sales amount to $70 \%$ of the total sales. } & & & \\
\hline \multicolumn{6}{|c|}{ The gross profit margin is $30 \%$ on turnover } \\
\hline \multicolumn{6}{|c|}{$\begin{array}{l}80 \% \text { of all trading inventory is bought on credit. Creditors are paid } 2 \text { months after the transaction and } \\
5 \% \text { discount received. A basic stock level is maintained at all times. }\end{array}$} \\
\hline
\end{tabular}

FIGURE 27: Consider the following example from second-year accounting.

\begin{tabular}{|c|c|c|c|c|c|c|c|}
\hline \multicolumn{8}{|l|}{ Solution } \\
\hline \multicolumn{8}{|c|}{ Cash Budget workings - Table method. } \\
\hline & & \multicolumn{2}{|c|}{ Nov } & \multicolumn{2}{|l|}{ Dec } & Jan & Feb \\
\hline \multicolumn{2}{|l|}{ Cash sales $(30 \%)$} & \multicolumn{2}{|c|}{37500} & \multicolumn{2}{|c|}{45000} & 41250 & $A=37500$ \\
\hline \multicolumn{2}{|c|}{ Credit sales $(70 \%)$} & \multicolumn{2}{|c|}{87500} & \multicolumn{2}{|c|}{105000} & 96250 & 87500 \\
\hline \multicolumn{2}{|c|}{\begin{tabular}{|l|} 
Sales $(100 \%)$ \\
\end{tabular}} & \multicolumn{2}{|c|}{125000} & \multicolumn{2}{|c|}{150000} & 137500 & 125000 \\
\hline \multicolumn{8}{|c|}{ Debtors collection schedule for January and February 2015.} \\
\hline \multicolumn{2}{|l|}{ Months } & \multicolumn{2}{|c|}{ January } & \multicolumn{3}{|c|}{ February } & \\
\hline \multicolumn{2}{|l|}{ November } & \multicolumn{2}{|c|}{13125} & & \\
\hline \multicolumn{2}{|l|}{\begin{tabular}{|l} 
December \\
\end{tabular}} & \multicolumn{2}{|c|}{52500} & \multicolumn{3}{|c|}{15750} & \\
\hline \multicolumn{2}{|l|}{ January } & \multicolumn{2}{|c|}{28875} & \multicolumn{3}{|c|}{48125} & \\
\hline \multirow{2}{*}{\multicolumn{2}{|c|}{ February }} & \multirow{2}{*}{\multicolumn{2}{|c|}{$B=9450$}} & \multicolumn{3}{|c|}{26250} & \\
\hline & & & & \multicolumn{3}{|c|}{90125} & \\
\hline \multicolumn{8}{|c|}{ Creditors payment schedule for January and February 2015.} \\
\hline & \multicolumn{2}{|l|}{ November } & Decen & ber & Jan & & February \\
\hline Cost of sales & $\begin{array}{l}125000 \times \\
=87500\end{array}$ & $\frac{70}{100}$ & $\begin{array}{l}15000 \\
10500\end{array}$ & $0 \times \frac{70}{100}$ & $\begin{array}{l}13 \\
96\end{array}$ & $500 \times \frac{70}{100}$ & $\begin{array}{l}125000 \times \frac{70}{100} \\
87500\end{array}$ \\
\hline $\begin{array}{l}\text { Cash purchases } \\
(20 \%)\end{array}$ & 17500 & & 21000 & & & 19250 & 17500 \\
\hline $\begin{array}{l}\text { Credit } \\
\text { Purchases } \\
(80 \%)\end{array}$ & 70000 & & 84000 & & 77 & & 70000 \\
\hline $\begin{array}{l}\text { Payments to } \\
\text { creditors }\end{array}$ & & & & & & $\begin{array}{l}00 \times 0,95 \\
500\end{array}$ & $\begin{array}{l}84000 \times 0,95 \\
\boldsymbol{D}=\mathbf{7 9 8 0 0}\end{array}$ \\
\hline
\end{tabular}

FIGURE 28: Cash budget solutions and workings.

should know how to calculate mark-up percentage, percentage increase or decrease (e.g. in salaries and wages). This means that mathematical reasoning is important and requires a great deal of practice. Students not able to identify amounts and having mathematical deficiencies in performing percentage calculations may find this section challenging.

\section{The topics in accounting and mathematics compared to find a relationship}

Table 3 and Figure 29 show that in the analysis of the accounting course packs, each time a specific part of any transaction, adjustment or additional information under each accounting topic was noted or observed that involved mathematical calculations, calculation was then done and linked to the list of mathematics topics.
I will illustrate the transdisciplinary relationship between Mathematics and Accounting with the specific topics in mathematics used in accounting.

\section{Findings}

The analysis has revealed that basic mathematics skills are crucial to understanding accounting. It is evident that BEd Accounting students need to be confident of their ability to work with calculations, as many topics illustrated in the examples indicate that most of mathematics (about $90 \%$ of it) required in BEd Accounting should have been covered at GET Mathematics (Grades R-9); this would include for instance, place-value numerical system, basic arithmetic operations, integers, ratios and proportions, formulas, linear equations, mathematical modelling and exponents. Only a small part of FET Mathematics, Grades 10-12, is required for accounting, such as number patterns, averages and weighted averages, projections, logarithms and financial mathematics.

The analysis of course packs confirmed that the mathematical content is needed for accounting, as indicated in the literature review. Accounting examples provided under each mathematical topic showed that transforming accounting data, through mathematical processes and logic, into useful information for accounting decision-making requires students to understand Polya's (1957) practical rules for solving skills for word problems: understand the problem; devise a plan; carry out the plan; and finally, look back and check your answer. In accounting, students must be able to try other methods if they experience a mental block.

It has been shown from the analysis of course packs that algebraic method is important in accounting as it applies to the majority of mathematical accounting problems, meaning that the algebraic method is important for students to know and understand. The algebraic method is also helpful for showing formula from each last but one step of the solution. If students are not happy about an answer they get using a formula, they can simply verify the answer by performing calculations using algebraic method. For students to master 


\begin{tabular}{|c|c|c|c|c|c|c|c|c|c|c|c|c|}
\hline \multicolumn{2}{|r|}{ BEd (Accounting) } & \multicolumn{11}{|c|}{ Mathematical topics } \\
\hline & & \multirow{5}{*}{ 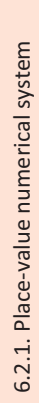 } & \multirow{5}{*}{ 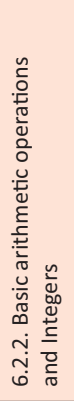 } & \multirow{5}{*}{ 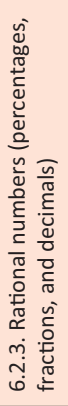 } & \multirow{5}{*}{ 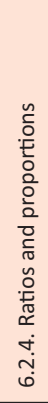 } & \multirow{5}{*}{ 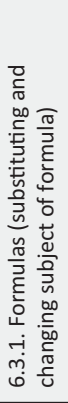 } & \multirow{5}{*}{ 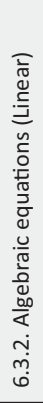 } & \multirow{5}{*}{ 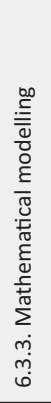 } & \multirow[b]{5}{*}{ 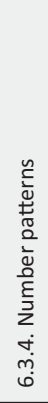 } & & \multirow{5}{*}{ 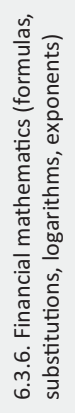 } & \multirow{5}{*}{ 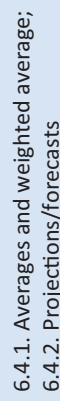 } \\
\hline & 6.2. Number and operations & & & & & & & & & & & \\
\hline & 6.3. Patterns and algebra & & & & & & & & & & & \\
\hline & 6.4. Data handling and probabilities & & & & & & & & & & & \\
\hline & & & & & & & & & & $\begin{array}{l}\frac{\tilde{v}}{0} \\
\stackrel{0}{\sigma} \\
\tilde{n} \\
\ddot{n}\end{array}$ & & \\
\hline \multirow{24}{*}{ 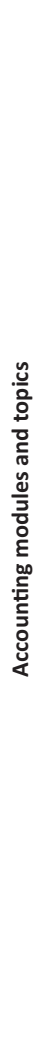 } & \multicolumn{12}{|l|}{ First-year accounting } \\
\hline & Accounting equation & $\times$ & $x$ & $x$ & $x$ & $x$ & $x$ & $x$ & - & $x$ & $x$ & - \\
\hline & Subsidiary books and source documents & $\times$ & $x$ & $x$ & $x$ & $x$ & $\times$ & $\times$ & - & $x$ & $\times$ & - \\
\hline & Salaries and wages & $\times$ & $x$ & $x$ & $x$ & $x$ & $x$ & $x$ & - & $x$ & $x$ & - \\
\hline & Final accounts and financial statement of a sole trader & $\times$ & $x$ & $x$ & $\times$ & $\times$ & $x$ & $\times$ & $\times$ & $x$ & $x$ & - \\
\hline & Bank reconciliation & $\times$ & $\times$ & $x$ & $\times$ & $\times$ & $\times$ & $\times$ & - & $\times$ & $x$ & - \\
\hline & Periodic inventory system & $\times$ & $x$ & $\times$ & $\times$ & $\times$ & $\times$ & $\times$ & - & $\times$ & $\times$ & $\times$ \\
\hline & Disposal of assets & $\times$ & $\times$ & $x$ & $\times$ & $\times$ & $\times$ & $\times$ & - & $x$ & $x$ & - \\
\hline & Financial statements: sole trader & $x$ & $x$ & $x$ & $x$ & $x$ & $x$ & $x$ & $x$ & $x$ & $x$ & - \\
\hline & Ratio analysis: sole trader & $x$ & $x$ & $x$ & $x$ & $x$ & $x$ & $x$ & - & $x$ & $x$ & $x$ \\
\hline & \multicolumn{12}{|l|}{ Second-year accounting } \\
\hline & Partnerships & $\times$ & $x$ & $\times$ & $x$ & $x$ & $x$ & $x$ & $x$ & $x$ & $x$ & $x$ \\
\hline & Companies & $\times$ & $x$ & $\times$ & $x$ & $x$ & $\times$ & $\times$ & $x$ & $x$ & $\times$ & $\times$ \\
\hline & Cash flow statements & $\times$ & $\times$ & $x$ & $\times$ & $x$ & $\times$ & $\times$ & - & $\times$ & $x$ & - \\
\hline & Ratio analysis: partnerships and companies & $\times$ & $x$ & $x$ & $x$ & $x$ & $x$ & $\times$ & - & $x$ & $x$ & $x$ \\
\hline & Close corporation & $x$ & $x$ & $x$ & $x$ & $x$ & $x$ & $\times$ & $\times$ & $x$ & $\times$ & $\times$ \\
\hline & Cash budgets and projections & $\times$ & $\times$ & $\times$ & $\times$ & $\times$ & $\times$ & $\times$ & - & $\times$ & $\times$ & $\times$ \\
\hline & Ratio analysis for $\mathrm{CC}^{\prime} \mathrm{s}$ & $\times$ & $\times$ & $x$ & $x$ & $x$ & $\times$ & $\times$ & - & $x$ & $\times$ & $x$ \\
\hline & \multicolumn{12}{|l|}{ Third-year accounting } \\
\hline & Sports clubs & $\times$ & $x$ & $x$ & $\times$ & $\times$ & $\times$ & $\times$ & - & $\times$ & $\times$ & - \\
\hline & Stock valuation & $x$ & $x$ & $x$ & $x$ & $x$ & $x$ & $x$ & - & $x$ & $x$ & $x$ \\
\hline & Manufacturing concerns & $\times$ & $x$ & $\times$ & $\times$ & $\times$ & $\times$ & $\times$ & - & $\times$ & $\times$ & $\times$ \\
\hline & Value-added tax (VAT) & $x$ & $x$ & $x$ & $x$ & $x$ & $x$ & $x$ & - & $x$ & $x$ & - \\
\hline & Ratio analysis: clubs and manufacturing concerns & $x$ & $x$ & $x$ & $x$ & $x$ & $x$ & $\times$ & - & $x$ & $x$ & $x$ \\
\hline
\end{tabular}

FIGURE 29: Bachelor of Education Accounting curriculum: Elements of mathematics knowledge and skills.

algebraic method, they must be familiar with proportional fractions and equations.

The calculations performed during the analysis of course packs make it clear that students must show workings or provide or supply a detailed calculation to support their answers, as marks in accounting are awarded for what is shown. Students must make sure that workings are crossreferenced to the final solution.

\section{Conclusion}

The analysis of BEd Accounting course packs showed the importance of number operations: the place-value numerical system; basic arithmetic operations; rational numbers (e.g. percentages, fractions and decimals); integers, averages and weighted average; and ratios and proportions. These topics are covered in Grades R-9 GET Mathematics.
Also apparent from the analysis of BEd Accounting course packs was the importance of patterns and algebra: formulas, substituting and changing subject of formula; linear equations; mathematical modelling; tables; time value of money and exponents. These topics are covered in Grades R-9 GET Mathematics at school level.

The mathematical topics that were found to be important were as follows: number patterns, when calculating depreciation using sum-of-the-digits method; exponents, when performing time value of money activities; and logarithms, when calculating date on which a loan or investment was reduced or increased. Number patterns, exponents and logarithms are found in the Grades 10-12 FET Mathematics, as are time value of money formulas (e.g. simple and compound interest and simple and compound depreciation). Time value of money is part of both Grades 10-12 FET Mathematics and Grades 10-12 FET Mathematical Literacy (Department of Basic Education 2003). 
For lecturers, in-service teachers and subject advisers, the results of this study will assist with the delivery of the accounting curriculum and provide learning approaches that might alleviate negative attitudes towards mathematics. The analysis of accounting course packs showed, for example that table method algebra is important in accounting as it assists in getting the answers in almost all mathematical accounting tasks in each accounting module and also indicates a formula that students can use as an algorithm. The formula is derived from the last but one step from the answer. To master the table method algebra, students must know proportional fractions and linear equations. Because students are advised to show workings or supply a detailed calculation to support their answers as marks in accounting are awarded for what is shown, they need to make sure that workings are cross-referenced to the final solution. It was also found that transforming accounting data through a mathematical process, logic and application into useful information for accounting decision-making requires students to understand Polya's (1957) practical rules for solving word problems.

\section{Implications for lecturers, in-service teachers and subject advisers}

Lecturers, in-service teachers and subject advisers should follow the accounting calculation methods indicated in this study, as this will assist with the delivery of the accounting curriculum in higher education and basic education. The accounting calculation methods provide innovative learning approaches that might assist in alleviating negative attitudes towards mathematics.

\section{Implications for textbook writers, curriculum specialists and international policymakers}

Textbook writers, curriculum specialists and international and national policymakers are encouraged to include the accounting calculation methods indicated in this study as this will assist students experiencing difficulties with mathematics.

\section{Acknowledgements}

\section{Competing interests}

The author declares that he has no financial or personal relationships which may have inappropriately influenced him in writing this article.

\section{References}

Babalola, Y.A. \& Abiola, F.R., 2013, 'The importance of mathematics in the recording and interpretation of accounting', International Journal of Financial Economics 1(4), 104-107.

Barnes, H., Dzansi, D., Wilknson, A. \& Viljoen, M., 2009, 'Researching the first year accounting problem: Factors infuencing success or failure at South African Highe Education Institution', Journal of New Generation Sciences 7(2), 36-58.
Budnick, F.S., 1993, Applied mathematics for Business, Economics, and the Social Sciences, 4th edn., McGraw-Hill, Singapore.

Chinn, S., 2008, 'Mathematics anxiety in secondary students in England', Dyslexia 15, 61-68. https://doi.org/10.1002/dys.381

Clark, C.E. \& Schwartz, B.N., 1989, 'Accounting anxiety: An experiment to determine the effects of an intervention on anxiety levels and achievement of introductory Accounting students', Journal of Accounting Education 7, 149-169. https://doi. org/10.1016/0748-5751(89)90002-X

Costello, R. \& Darnley, G., 2009, A discussion of maths learning, Mathematics, Australia, pp. 1-39. Department of Education, Australia.

Department of Basic Education, 2003, National Curriculum Statement Grades 10-12, Department of Basic Education, Pretoria.

Ellerman, D., 2007, Double-Entry accounting: The mathematical formulation and generalization', FSR Forum (Financial Studies Association Rotterdam), 17-22 February.

Fedoryshyn, M.W., O'Brien, E., Hintz, A. \& Bosner, K., 2010, 'Arithmetical reasoning skills as a predictor of success in principles of accounting', Academy of Educational Leadership Journal 14, pp. 93-107.

Gist, W.E., Goedde, H. \& Ward, B.H., 1996, 'The influence of mathematical skills and other factors on minority student performance in principles of accounting', Accounting Education 11(1), pp. 49-57.

Haiden, M., 2009, Accounting makes cents! 7th edn., Acc-Tuition CC, Durban North.

Heck, A. \& van Gastel, L., 2006, 'Mathematics on the threshold', International of Mathematics Education in Science and Technology 37(8), 925-945.

HEI, 2013, College of humanities handbook, Higher Education Institution, Durban.

Jacobs, M.S., 2006, A description of entry level tertiary students' mathematical achievement, Doctor of Philosophy, University of Western Cape, Cape Town.

Koh, M.Y. \& Koh, H.C., 1999, 'The determinants of performance in an accountancy degree programme', Accounting Education Next 8(1), 13-29. https://doi.org/ 10.1080/096392899331017

Latief, A., 2005, 'Throughput of UWC students who did at least one semester of thirdyear statistics', Unpublished Master's Mini-Thesis, University of Western-Cape, Cape Town.

Mattessich, R., 2005, 'A concise history of analytical accounting: Examining the use of mathematical notions in our disciple', Spanish Journal of Accounting History 2, 123-153.

Mostyn, G., 2008a, Essential Math for Accounting: Part I, Worthy and James Publishing, New York.

Mostyn, G., 2008b, Essential Math for Accounting: Part II, Worthy and James Publishing, New York.

Myburgh, J.E., Fouche, J.P. \& Cloete, M., 2011, Accounting - An introduction, LexisNexis, Durban.

Naidoo, T., 2012, An exploration of first-year, non-major accounting students' learning experiences at a private higher education institution in South Africa, Master of Education, University of KwaZulu-Natal, KwaZulu-Natal.

Naser, K. \& Peel, M.J., 1998, 'An exploratory study of the impact of intervening variables on student performance in a principles of accounting course', Accounting Education: An International Journal 7(2), 209-223. https://doi.org/10.1080/ Education: An Intern

Polya, G., 1957, How to solve it? A new aspect of mathematical method, Princeton University Press, Princeton.

Pritchard, R., Potter, G. \& Saccucci, M., 2004, 'The selection of a business major: Elements influencing student choice and implications for outcomes assessment', Journal of Education for Business 79(3), 152-156. https://doi.org/10.3200/ Journal of Education
JOEB.79.3.152-156

Rossman, S., 2006, 'Overcoming maths anxiety', Mathitudes 1, 1-4.

SAICA, 2010, 'Future of South Africa's economy and financial services sector at risk due to shortage of good school mathematics matrics', News and Press Archives SAICA, 1-2, viewed 25 August 2014, from https://www.saica.co.za/News/ SAICA, 1-2, viewed 25 August 2014, from https://www.saica.co.za/News/
NewsArticlesandPressmediareleases/2010/tabid/2313/itemid/2728/language/ en-ZA/Default.aspx

Schwab, K., Sala-i-Martin, X. \& Brende, B., 2013, 'The global competitiveness report', in K. Schwab (ed.), World Economic Forum committed to improving the state of the world, pp. 569, World Economic Forum, Geneva.

Selesho, J.M., 2000, An investigation into factors that influence the results of accounting (education I at the Technikon Free State, (Magister Technologiae Education), Port Elizabeth Technikon, Port Elizabeth.

Serai, Y., 2014, Degrees in accounting and mathematics, viewed 29 August 2014, from http://ehow.com/info_7976898_degrees-accounting-mathematics=similarities. html

Shaftel, J. \& Shaftel, T., 2005, 'The influence of effective teaching in accounting on student attitudes, behaviour, and performance', Issues in Accounting Education 20(3), 231-246. https://doi.org/10.2308/iace.2005.20.3.231

Shi, X. \& Paucar-Caceres, A., 2011, The impact of learning maths on studying accounting and finance course at University Level Business, Management, Accounting and Finance Network, Manchester Metropolitan University, Manchester.

Stainbank, L., 2013, 'The impact of NSC mathematics on the performance of first year commerce students', Alternation Special Edition 8, 107-121. 
Stenberg, L., Varua, M.E. \& Yong, J., 2010, 'Mathematics aptitude, attitude, secondary schools and student success in quantitative methods for business subject in an
Australian Catholic University Experience', Paper presented at the 39th Australian Australian Catholic University Experience, Paper present
Conference of Economists, Sydney, 27-29 September.

Tahir, I.M. \& AbuBakar, N.M., 2007, 'Business students' beliefs in learning mathematics', Journal Kemanusiaan bil 10, 90-103.

Thomason, K., 2013, Importance of mathematics to accounting, viewed 26 January 2013 from http://www.eHow.com/info 8665958 importance-mathematics-accounting.htm

University of Glasgow, 2014, Undergraduate degree programmes: Accounting and mathematics, viewed 27 August 2014, from http://www.gla.ac.uk/undergraduate/ degrees/accountingmathematics/
Walton, M., 2009, 'Mathematical requirements for first-year B Com students at NMMU', Doctor of Philosophy, Nelson Mandela Metropolitan University, Port Elizabeth.

Warsono, S., Darmawan, A. \& Ridha, M.A., 2009, 'Using mathematics to teach accounting principles', Social Science Research Network 1(2), 1-25.

Webster, M., 2018, Definition of mathematics, viewed 28 August 2014, from www. learnersdictionary.com/definition/mathematics

Yunker, P.J., Yunker, J.A. \& Krull, G.W., 2009, 'The influence of mathematics ability on performance in principles of accounting', The Accounting Educators' Journal XIX, 1-20. 